\title{
EMPREGO DA PROTEINNA DO FARELO DE MAMONA DESTOXICADO, EM SUBSTITUIÇÃO A PROTEÍNA DO \\ FARELO DE SOJA, NA ALIMENTAÇÃO \\ DE FRANGOS DE CORTE
}

\author{
JOCELYN SANTIIAGO BRANDÃO
}

Orientador: Roberto Dias de Moraes e Silva

Dissertação apresentada à Escola Superior de Agricultura "Luiz de Queiroz", da Universidade de São Paulo, para obtenção do título de Mestre em Nutrição Animal e Pastagens.

$P \mid R A C I C A B A$

Estado de São Paulo - Brasil

Novembro, 1977 


\section{DEDICO :}

A minha esposa, ROZA DE IOURDES, pela ajuda e estimulo em todas as horas.

As minhas filhas, THAis e TATIAYA, pelos momen tos de alegria revigorantes.

Aos meus pais, JOCELIN e LOURDES, que con sacrifício e perseverança, me orientaram pelos caminhos da vida. 
AGRADECIMENTOS

Ao Prof. Dr. ROBERTO DIAS DE MORAES E SIIVA, pela orientação no Curso de Pós-Graduação e neste trabalho.

Ao Dr. JOSE EDUARDO BUTOIO, pelas sugestões apresentadas na organização e desenvolvimento do experimento e na redação final deste trabalho.

Aos Professores do Curso de Pós-Graduação en "Nutrição Animal e Pastagens", pelos ensinamentos ministrados.

A Escola Superior de Agricultura "Luiz de Queiroz", pelo Cur so de Pós-Graduação em "Nutrição Animal e Pastagens".

A DuRatex S/A. Indústria e Comércio (Rações Anhanguera S/A), pelo fornecimento dos animais, instalações e componentes utilizados no preparo das raçōes experimentais e pelas análises químicas bromatológicas dessas rações, realizadas no seu Iaboratório de Controle de Qualidade.

Ao Dr. JULIO JEOVAH NASCIMENTO SILVEIRA, pelo auxilio presta do nas análises laboratoriais.

Ao Programa de Educação Agrícola Superior - PEAS, pela concessão da Bolsa de Estudos.

A Universidade Federal da Paraíba, pela oportunidade que me foi dada para realizar esse curso. 
AO PROf. MOACIR OMENA DE OLIVEIRA, pelo espírito de solidariedade e companheirismo.

Aos funcionários do Centro de Experimentação e Pesquisa Anhanguera - CEPA, pelo apoio e interesse em solucionar os problemas surgidos no transcorrer do trabalho experimental.

E a todos aqueles que, direta ou indiretamente, contribuiram para a realização deste trabalho. 
3. REVISATO DE IITERATURA $\ldots \ldots \ldots \ldots \ldots \ldots \ldots \ldots \ldots \ldots$

3.1. Produção de mamona ................. 5

3.2. Toxidez do farelo de mamona ............ ?

3.2 .1 . A ricina $\ldots \ldots \ldots \ldots \ldots \ldots \ldots \ldots \ldots$ ?

3.2.2. A ricinina ................ 8

3.2.3. A fração alergênica .............. 9 9

3.3. Valor alimenticio do farelo de mamona desto-

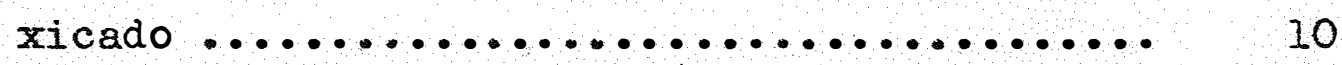

3.4. Farelo de mamona destoxicado na alimentaçäo

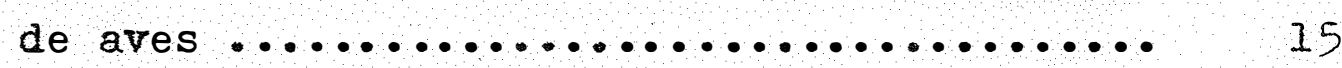

3.5. Poder laxativo do bleo de mamona ...........

4. MATERTAL E METODOS $\ldots \ldots \ldots \ldots \ldots \ldots \ldots \ldots \ldots \ldots \ldots 22$

4.1. Instalações e equipamentos $\ldots \ldots \ldots \ldots \ldots \ldots . . . .22$

4.2. Períodos de criação .................. 24

4.3. Delineamento experimental ............. 24

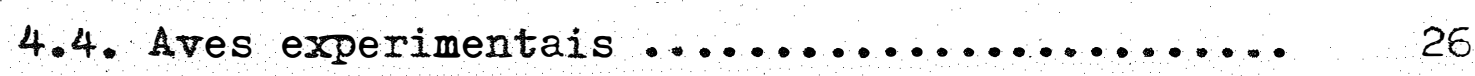

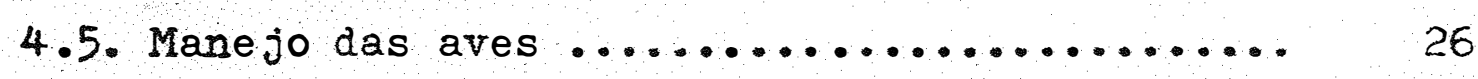

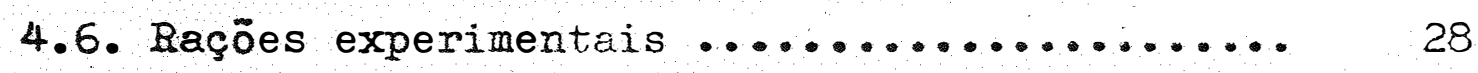

4.7. Peso corporal, consumo de ração e conversäo alimentar ......................... 39

4.8. Mortalidade ....................... 39 
Página

4.9. Erro de sexagem .................... 39

4.10. Análise bio-económica ................. 40

5. RESULTADOS ......................... 43

5.1. Peso médio, consumo alimentar médio e conver são alimentar média das aves, aos 35 dias de idade ............................

5.2. Ganho de peso médio, consumo alimentar médio e conversão alimentar média das aves, entre 36 e 56 dias de idade .................

5.3. Peso médio, consumo alimentar médio e conver são alimentar média das aves, aos 56 dias de idade $\ldots \ldots \ldots \ldots \ldots \ldots \ldots \ldots \ldots \ldots \ldots \ldots$

59

5.4. Mortalidade $\ldots \ldots \ldots \ldots \ldots \ldots \ldots \ldots \ldots \ldots \ldots 6 \ldots$

5.5. Erro de sexagem $\ldots \ldots \ldots \ldots \ldots \ldots \ldots \ldots \ldots \ldots 66$

5.6. Análise bio-econômica ................... 67

5.7. Controle de coccidiose e verminose ........ 68

5.8. Efeito laxativo do olleo de mamona ......... 68

6. DISCUSSEO $\ldots \ldots \ldots \ldots \ldots \ldots \ldots \ldots \ldots \ldots \ldots \ldots \ldots \ldots \ldots \ldots \ldots$

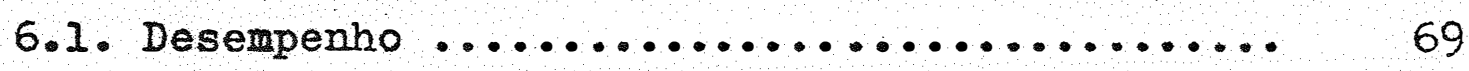

6.1.1. Peso médio, consumo e conversāo alimentares médios das aves, aos 35 dias de idade ...................... 69

6.1.2. Ganho de peso médio, consumo e conver são alimentares médios das aves, entre 36 e 56 e entre 0 e 56 dias de i-

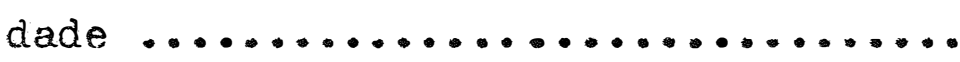


6.2. Estudo econômico da utilização do farelo de mamona destoxicado em rações de frangos de

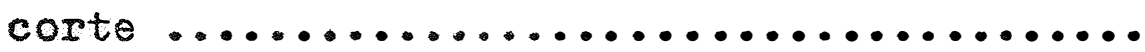

7. CONCLUSOES $\ldots \ldots \ldots \ldots \ldots \ldots \ldots \ldots \ldots \ldots \ldots \ldots \ldots \ldots \ldots \ldots \ldots \ldots \ldots$

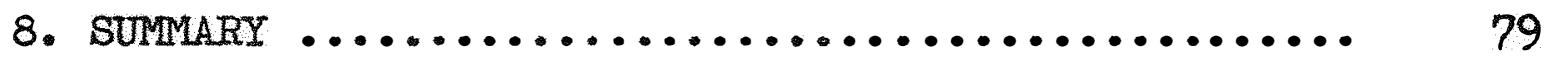

9. IITERATURA CITADA $\ldots \ldots \ldots \ldots \ldots \ldots \ldots \ldots \ldots \ldots$

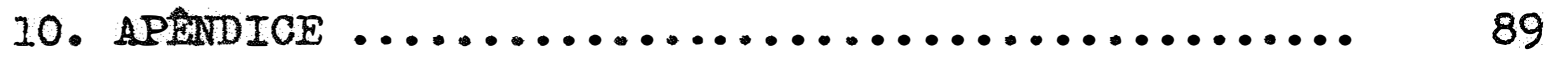


Tabela 1. Países produtores de mamona, em bagas .... 6

Tabela 2. Estados produtores de mamona, em bagas ... 6

Tabela 3. Composição quimica bromatológica percentual dos farelos de diferentes oleaginosas

Tabela 4. Aminograma dos farelos de diferentes olea-

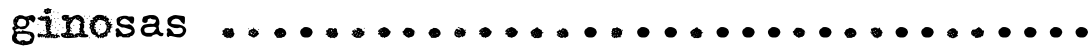

Tabela 5. Composição química bromatológica dos ingre dientes utilizados na elaboração das raçōes

Tabela 6. Aminograma dos ingredientes utilizados na elaboração das rações .................

Tabela 7. Composição percentual das rações iniciais.

Tabela 8. Composição quínica bromatológica calculada das rações iniciais .................

Tabela 9. Aminograma calculado das rações iniciais .

Tabela 10. Composição percentual das rações finais.

Tabela 11. Composiçāo química bromatológica calcula-

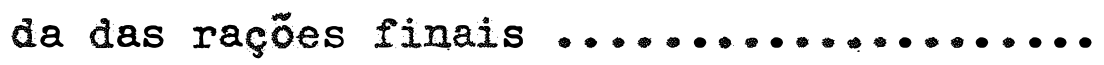

Tabela 12. Aminograma calculado das rações finais ..

Tabela 13. Peso médio, consumo alimentar médio e con versão alimentar média das aves aos 35

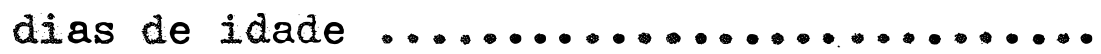

Pabela 14. Análise de variância do peso médio das a-

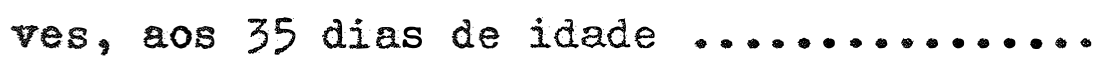


Página

Tabela 15. Análise de variância do consumo alimentar médio das aves, aos 35 dias de idade .... 46

Tabela 16. Análise de variância da conversāo alimentar média das aves, aos 35 dias de idade.

Tabela 17. Ganho de peso médio, consumo alimentar mé dio e conversão alimentar média das aves, entre 36 e 56 dias de idade ........... 52

Tabela 18. Análise de variância do ganho de peso médio das aves, entre 36 e 56 dias de idade

Tabela 19. Análise de variância do consumo alimentar médio das aves, entre 36 e 56 dias de ida

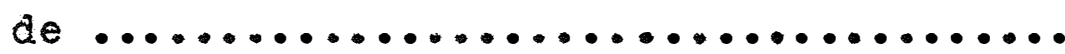

Tabela 20. Anålise de variância da conversão alimentar média das aves, entre 36 e 56 dias de idade

Tabela 21. Peso médio, consumo alimentar médio e con versão alimentar média das aves, aos 56

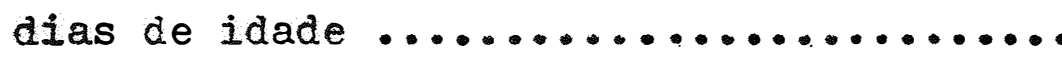

Tabela 22. Análise de variância do peso médio das a-

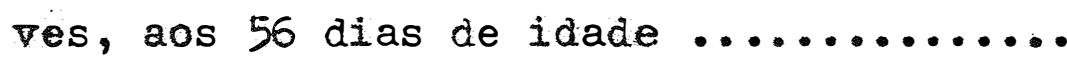

Pabela 23. Análise de variância do consumo alimentar médio das aves, aos 56 dias de idade ....

Tabela 24. Análise de variância da conversão alimentar média das aves, aos 56 dias de idade.

Tabela 25. Exro de sexagem verificado durante 0 expe

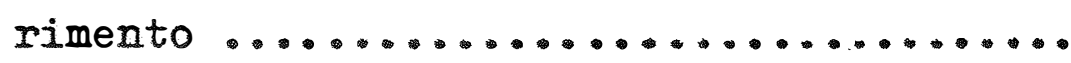


Tabela 26. Iucro médio relativo, por tratamenta por ave, aos 35 e 56 dias de idade ......

Pabela 27. Peso médio, consumo de ração médio e conversão alimentar média, nas parcelas, aos 35 dias de idade das aves ..............

Tabela 28. Ganho de peso médio, consumo de ração médio e conversão alimentar média, nas parcelas, entre 36 e 56 dias de idade das aves $\ldots \ldots \ldots \ldots \ldots \ldots \ldots \ldots \ldots \ldots \ldots \ldots \ldots \ldots$

91

Tabela 29. Peso médio, consumo de ração médio e conversão alimentar média, nas parcelas, aos 56 dias de idade das aves .............

Tabela 30. Valores médios da umidade relativa do ar e das temperaturas mílima, média e máxima durante $\circ$ experimento ................ 
Figura 1. Representação gráfica da regressão do peso médio das aves, aos 35 dias de idade .....

Figura 2. Representação gráfica da regressão do consumo alimentar médio das aves, aos 35 dias de idade ..........................

Figura 3. Representação gráfica da regressão da conversão alimentar média das aves, aos 35 dias de idade ......................

Figura 4. Representação gráfica da regressão do consumo alimentar médio das aves, entre $36 \mathrm{e}$

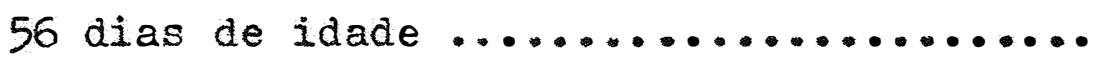

Pigura 5. Representação gráfica da regressão da conversão alimentar média das aves, entre 36

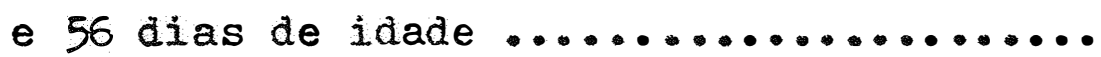

Figura 6. Representação gráfica da regressão do consumo alimentar médio das aves, aos 56 dias de idade ...........................

Figura 7. Representação gráfica da regressão da conversão alimentar média das aves, aos 56 dias de idade 
NOME: JOCELYN SANTIAGO BRANDAO

DATA DO NASCIMENTO: 23 de fevereiro de 1945

IOCAI DO NASCIMENTO: João Pessoa, PB, Brasil

FORMAÇÃO UNIVERSTTARIA: Engenheiro Agrônomo, 1968, pela Esco la de Agronomia do Nordeste, Areia, PB.

ATIVIDADE ATUAL: Professor Auxiliar de Ensino do Departamento Agro-Zootécnico do Curso de Agronomia do Centro de Ciências e Tecnologia da Universi dade Fecieral da Paraiba, Areia, PB. 
1. RESUMO

O presente trabalho visou estudar os efeitos da substituição da proteína do farelo de soja pela proteína do farelo de mamona destoxicado, na alimentação de frangos de corte. 0 farelo de mamona destoxicado utilizado foi 0 "Lex Proteico", nome comercial do produto fabricado pela SANBRA (Sociedade Algodoeira do Nordeste Brasileiro S.A.).

Foram utilizados 864 pintos "Peterson", dirí didos em 24 parcelas com 18 aves de cada sexo, por parcela. Foram utilizados seis tratamentos, com quatro repetições em delineamento em blocos casualizados. Os tratamentos foram representados por seis diferentes raçöes, onde tanto na fase inicial ( $0-35$ dias), quanto na final (36-56 dias), a pro teina do farelo de mamona substituiu, respectivamente, 0 , $10,20,30,40$ e $50 \%$ da proteina do farelo de soja.

As ares receberam água e ração "ad libitum" e foram pesadas semanalmente, a partir dos 14 dias até os 56 dias de jdade (fim do experimento). Na ocasiāo das pesa gens eram calculados o consumo e a conversão alimentares.

Os tratamentos mostraram diferenças significativas para os resultados obtidos quanto ao peso médio, 
consumo e conversão alimentares, aos 35 dias, entre 36 e 56 e aos 56 dias de idade das aves. Quando os graus de liberdade dos tratamentos foram subdivididos em seus componentes de regressão, foram encontrados os seguintes resultados: Aos 35 dias de idade, resposta quadrática $(P<0,01)$ para os níveis de adição do farelo de mamona às rações, no tocan te a peso médio. 0 maior peso médio obtido nesta fase foi ao nivel de $30 \%$ de substituição, ou seja, $11,60 \%$ de farelo de mamona na ração. Para consumo alimentar foi encontrada resposta linear positiva $(P<0,01)$ e para conversão alimen tar, resposta quadrática positiva $(P<0,05)$ à adição de ní veis crescentes do farelo de mamona às rações.

Na fase final (36-56 dias) e no total do experimento (0-56 dias), o nivel de substituiçäo que promoveu maior ganho de peso foi o de 10\%, em ambos os períodos. Pa ra consumo alimentar, houve resposta cúbica positiva $(P<0,05)$ e para conversäo alimentar, houve resposta linear positiva, aos niveis de substituiçäo, tanto no periodo final, quanto no total do experimento.

Estas respostas obtidas nas análises de regressão sugerem ter havido diminuição no teor energético das raçōes, à medida que aumentaram os niveis de adição de farelo de mamona.

Nas condições do presente experimento, os re sultados do estudo bio-econômico realizado mostraram vantagem significativa para a ração que recebeu o nivel de $10 \%$ de substituição da proteína do farelo de soja pela do de ma mona, em relação às rações que receberam substituição de 40 e 50\%, tanto na fase inicial, quanto na final. 
2. INTRODUÇAO

A demanda mundial por novas fontes de proteína para alimentação animal tem tido, como consequência, a utilizaçāo de novos produtos, que antes năo eram empregados com es sa finalidade. O farelo de mamona (Ricinus communis $I_{.}$) é um desses produtos.

- Brasil è o maior produtor mundial de mamona, contribuindo com $35 \%$ da produção.

A semente, que contém até $50 \%$ de óleo, é o principal produto da mamoneira. Como subproduto da extraçāo do óleo, obtém-se a torta que vem sendo empregada, há muito tempo, como fertilizante e, há alguns anos, na alimentação animal, transformada em farelo.

Este farelo que contém 40 a $45 \%$ de proteina bruta, pode ser comprado a um preço inferior ao do farelo de soja, principal suplemento proteico atualmente utilizado.

Como na criação de aves, a alimentação representa cerca de $70 \%$ dos custos de produção, o uso de ingredien tes proteicos de menor preço, representará sensível economia, resultando em reduçăo do custo do produto produzido. 
Até alguns anos atrás, a toxidez da torta de mamona, devida à ricina, à ricinina e à fraçăo alergênica, impedia sua utilização na alimentação animal.

No ano de 1956, pesquisadores da Sociedade Al godoeira do Nordeste Brasileiro (SAMBRA) obtiveram processamento que removesse as substâncias tóxicas e alérgenas do produto, de maneira econômica, vindo a constituir o farelo de nome comercial "Lex Proteico".

Värios trabalhos experimentais, em especial com ruminantes, têm mostrado que esse farelo apresenta bons resultados em relação aos obtidos com farelos de outras olea ginosas, usualmente empregados na alimentaçăo animal. Pouco se sabe, no entanto, a respeito do seu valor nutritivo na alimentação de monogástricos, sendo bem poucos os trabalbos $\mathrm{e}$ xistentes acerca do seu emprego na alimentação de aves.

o "Iex Proteico" foi o produto utilizado no presente trabalho.

Este experimento tem como objetivo principal verificar os efeitos da substituiçäo, em níveis crescentes, da proteina do farelo de soja pela do farelo de mamona desto xicado, na alimentação de irangos de corte. 
3. REVISAO DA LTTERATURA

\subsection{Produção de mamona}

$$
\text { De acordo com a FAO (1975a), O Brasil é o }
$$
maior produtor mundial de mamona, sendo responsável por $35 \%$ da produção.

o nordeste do país é a região maior produtora, com a Bahia ocupando o primeiro lugar, segundo o I.B.G.E. (1976).

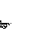

A Tabela 1 mostra os países produtores e a Tabela 2 mostra os Estados do Brasil, com suas produçōes, respectivamente. 
Tabela 1. Países produtores de mamona em bagas. Dados de 1975.

\begin{tabular}{lrr}
\hline Pais & Produção em t & $\%$ \\
\hline Brasil & 290.000 & 35,00 \\
India & 216.000 & 26,00 \\
China & 80.000 & 10,00 \\
U.R.S.S. & 60.000 & 7,00 \\
Tailândia & 34.000 & 4,00 \\
Outros & 150.000 & 18,00 \\
& & 100,00 \\
Total & 830.000 & \\
\end{tabular}

Fonte: FAO (19750)

Tabela 2. Estados produtores de mamona em bagas. Dados de 1976 .

\begin{tabular}{lcc}
\hline Estado & Produção em t & $\%$ \\
\hline Bahia & 92.000 & 43,20 \\
Paraná & 38.766 & 18,20 \\
Ceará & 28.500 & 13,40 \\
Såo Paulo & 28.500 & 13,40 \\
Pernambuco & 13.797 & 6,50 \\
Outros & 11.298 & 5,30 \\
\hline Total & 212.861 & 100,00
\end{tabular}

Fonte: I.B.G. 
De acordo com ROBB et elii (1974), as sementes da mamona fornecen $50 \%$ de óleo e $50 \%$ de torta.

De acordo com esses dados, a produção brasileí ra de torta, em 1976, foi de 105.000 toneladas, aproximadamen te.

Essa torta, após ser destoxicada e transformada em farelo, é vendida comercialmente ao preço de $\mathbb{E} \$ 1,50$. os outros ingredientes proteicos, como os farelos de algodão, amendoim e soja, custavam respectivamente, $₫ \$ 2,48, \Subset \$ 2,70$ e C\$3,41 por $\mathrm{kg}$, em març de 1977 , segundo o INSTITUTO DE BCOHO MIA AGRÍCOLA DO ESTADO DE SAO PAULO (1977).

\subsection{Toxidez do farelo de manona}

De acordo com WALIER e NEGI (1958) e JEMKINS (1963), a toxidez do farelo de mamona é devida a três fontes: uma proteína altamente tóxica, a ricina; um alcalóide ligeira mente tóxico, a ricinina, e una fraçăo alergênica que foi des crita como un complexo proteína-polissacarideo.

\subsubsection{A Ricina}

Investigando a purificação e as propriedades da ricina, KABAT et alii (1947) obtireram preparaçōes altamen te tóxicas, pela precipitação fracionada com sulfato de sódio. Concluiram ainda, que existem formas de ricina, tóxica e năo tóxica, que podem ser separadas por cristalização.

Segundo JONES (1947), a ricina já demonstrou ser tóxica para o homem, coelhos, porcos, bovinos, equinos, $\varrho$ vinos, cães, ratos, camundongos, cobaias, patos e galinhas. A toxicidade varia de acordo com a espécie animal e a cobaia parece ser a mais suscetivel.

De acordo com CORNEVIN, citado por JONES, (1947), a dose letal, em gramas de sementes de mamona por qui 
10 de peso vivo do animal, é a seguinte:

$$
\begin{array}{ll}
\text { coelhos }-2,0 \mathrm{~g} & \text { suínos }-3,5 \mathrm{~g} \\
\text { ovinos }-2,5 \mathrm{~g} & \text { cães }-5,6 \mathrm{~g} \\
\text { bovinos }-3,0 \mathrm{~g} & \text { galos }-40,0 \mathrm{~g} \\
\text { equinos }-3,0 \mathrm{~g} & \text { patos }-40,0 \mathrm{~g} \\
\text { Aparentemente, as aves säo mais resistentes }
\end{array}
$$

que os mamíferos à ação tóxica da ricina. Para o homem, a dose de $0,18 \mathrm{~g}$ por quilo de peso vivo, é letal.

ANDERSON (1948) descreveu a morte de vinte va cas da raça Ayrshire, como resultado do envenenamento pelas sementes da mamona.

Segundo JENKINS (1963), envenenamentos pelas sementes da mamona têm sido observados no homem e nos animais domésticos. En 1888, EDSON citado por JEMKINS (1963), descre veu vômitos e náuseas em quinze crianças que haviam comido, cada uma, quatro sementes de mamona. METDRUM em 1900, também citado por JEMKINS (1963), relata que duas sementes causaram a morte de un homem.

Segundo o mesmo autor, o cavalo parece ser o $\underline{a}$ nimal mais suscetível. Bovinos e suĺnos sāo mais resistentes aos efeitos tóxicos, sendo que os patos e as falinhas são os mais resistentes dos animais domésticos.

A ricina, de acordo com o mesmo autor, aglatina as células vermelhas do sangue de várias espécies animais. Causa paralisia dos sistemas cardíaco e circulatório, cólica, diarréia, perda de apetite e hemorragia intestinal. Há, apro ximadanente, un intervalo de três dias entre a ingestão e o a parecimento dos sintomas.

\subsubsection{A Ricinina}

A ricinina, segundo SPIES et aIii (1941), está presente em quantidades apreciáveis nas folbas, caules e se- 
mentes da mamona, mas raramente se encontra nas sementes aadu ras.

De acordo com AMBEKAR e DOLE (1957), a ricinina um alcalóide pouco tóxico. Quando o farelo de mamona $\dot{e}$ destoxicado pelo tratamento com amônia para destruir a ricina e o alérgeno, a quantidade de ricinina presente é reduzida pa ra aproximadamente 25\%. Segundo esses autores, a ricinina po de causar, quando inalada por pessoas sensiveis, asma e infla mação nos ollhos.

MURASE et alij (1966) concluiram que a ricinina inibiu o crescimento de aves alimentadas com farelo do namona destoxicado, quando usado ao nível de $40 \%$ na ração. 0 conteúdo de ricinina no farelo era de aproximadamente $0,13 \%$. A dose minima letal, por injeção intraperitoneal em camundongos, foi de 0,016mg de ricinina por grama de peso vivo; por via oral, em aves, foi de $0,1 \mathrm{mg}$ de ricinina por grama de peso vivo.

\subsubsection{A fração alergênica}

ALIJAIRE (1914) foi quem primeiro descreveu a hipersensibilidade do homem às sementes da mamona. Ele pröprio teve que abandonar suas pesquisas devido à violência dos sintomas. Descreveu comichão nos olhos, fotofobia, verme Ihidão da conjuntiva, lacrimejamento abundante, espirros violentos, tosse, dispnéia e urticária.

Pesquisas realizadas por FIGLEY e ELROD em 1928, demonstraram que os sintomas de asma apresentados por trinta pessoas residentes em Toledo, Ohio, eram causados pelo pó de sementes de mamona proveniente de uma fábrica de proces samento de óleo existente nas proximidades.

Pacientes sensíveis à fração alergênica tiveram reações cutâneas, de acordo com SPIES e COULSON (1943), quando receberam o alérgeno em uma diluição de $1: 10^{6}$. Fm co- 
bajas produziu sensibilidade e choque anafilátioo. A dose wí nima para produzir a seńsibilidade foi de $8,4 \mathrm{mg}$ do alérgeno e para produzir o choque, foi de $0,33 \mathrm{ug}$.

Segundo RAYMOND (1961), nenhum nome específico foi dado a esse princípio, mas é normalmente citado como CBA (castor beans aljergen). Este alérgeno năo tem ação tóxica visivel na primeira vez em que é administrado, mesmo que em grandes dosagens. No entanto, a administraçäo de pequenas do ses repetidas, faz aumentar a suscetibilidade do animal ao CBA.

\subsection{Valor alimenticio do farelo de mamona destoxicado}

Devido ao seu elevado teor em proteĺna, o fare 10 de mamona vem, há muito, prendendo a atençäo dos pesquisadores em nutrição animal.

- fare 10 de mamona contém, aproximadamente, 40 por cento de proteína, mas é deficiente nos aminoácidos essen ciais metionina, lisina e triptofano, de acordo com roDras et alii (1949). Segundo esses autores, essas deficiências não recomendarian o farelo para uso na alimentação de suínos e aves, mas poderia ser usado com ótimos resultados na alimentação de bovinos.

Pesquisas realizadas por PERRONE et alii, (1966) demonstraram que o conteúdo de aminó́cidos do farelo de manona é comparável aos do farelo de algodão e amendoim, já larga mente usados em raçōes para animais domésticos.

A Tabela 3 mostra a composição química bromato lógica e a rabela 4 mostra o aminograma, de farelos de diferentes oleaginosas, comumente usados em rações. 
Tabela 3. Composiçäo quínica bronatológica percentual dos farelos de diferentes oleaginosas.

\begin{tabular}{lrrrr}
\hline & Soja & Mamona & Algodäo ${ }^{2}$ & Amendoim ${ }^{2}$ \\
\hline Agua & 12,40 & 10,00 & 10,46 & 10,35 \\
Proteina bruta & 48,25 & 38,80 & 37,91 & 50,87 \\
Extrato etéreo & 1,07 & 0,96 & 1,44 & 1,39 \\
Matéria fibrosa & 5,43 & 19,50 & 16,60 & 9,36 \\
Matéria mineral & 5,22 & 6,70 & 9,82 & 5,29 \\
Ext. näo nitrogenado & 27,63 & 24,04 & 23,77 & 22,84 \\
& & & & \\
\hline
\end{tabular}

Fonte: 1. Dados obtidos pela análise das matérias primas usadas no experimento

2. ASSIS et al11 (1962) 
Tabela 4. Aminograma dos farelos de diferentes oleaginosas, considerado sobre $100 \%$ de proteína.

\begin{tabular}{lcccc}
\hline Aminoácidos & Soja & Mamona & Algodão & Amendoin \\
\hline Arginina & 7,0 & 11,0 & 7,4 & 9,9 \\
Cistina & 1,9 & 3,5 & 2,0 & 1,6 \\
Fenilalanina & 5,7 & 4,2 & 6,8 & 5,4 \\
Histidina & 2,3 & 2,5 & 2,6 & 2,1 \\
Isoleucina & 4,7 & 5,3 & 3,4 & 3,0 \\
Leucina & 9,6 & 7,2 & 5,0 & 7,0 \\
Lisina & 5,8 & 3,1 & 2,7 & 3,0 \\
Metionina & 2,0 & 1,5 & 2,1 & 1,2 \\
Tirosina & 4,1 & 1,0 & 3,2 & 4,4 \\
Treonina & 3,0 & 3,6 & 3,0 & 1,5 \\
Triptofano & 1,6 & 0,6 & 1,3 & 1,0 \\
Valina & 2,4 & 6,6 & 3,7 & 8,0 \\
\hline
\end{tabular}

Fonte: IOUREIRO (1962) 
Im 1934, PETROSYAN e PONOMAREV publicaram suas investigaçōes sobre a destoxicaçāo do farelo de mamona e sua utilizaçāo con êxito na alimentação de porcos.

- emprego da torta destoxicada na alimentaçāo de vacas foi investigado por BUTZ e BOTTGER (1937).

Em 1938, TANGI conseguiu eliminar os principios tóxicos da torta, aquecendo-a a 140 oc por 60 a 90 mimutos. Verificou que a torta tratada nessas condiçöes, quando usada na alimentação de ovelhas, não apresentou efeitos tóxicos.

En 1949, KODRAS et alii publicaram os resultados de suas investigaçōes relativas à destoxicação da torta de mamona. Após a destoxicação, a torta foí usada na alimentação de ratos e galinhas, sem apresentar nenhum sintoma de toxidez. O material obtido, porém, mostrou ser de baixo valor biológico.

Após destoxicar a torta de mamona, PRAKHII et alii, em 1952, utilizaram-na para alimentar porcos e vacas. Os animais tiveram um aumento na média de ganho de peso diário e durante todo o periodo experimental apresentaram boa es tado de saúde. Os porcos logo se acostumaram à torta de mano na, mas as vacas só gradualmente se adaptaram à sua ingestão. POLIAKOFF (1960) comentando o valor alimentício do farelo de mamona, concluiu que seu uso deve ser restri to aos ruminantes, pelo fato de apresentar un elevado teor de fibras.

Utilizaado torta de mamona destoxicada na alimentaçåo de novilhas leiteiras, MIRANDA et alii (1961) não constataram problemas quanto à aceitação pelos animais, nem alteração na saúde das novilhas que pudessem ser atribuídas a esse alimento.

A Sociedade Algodoeira do Nordeste Brasileiro S.A. (SAMBRA), citada por PERRONE et alii. (1966), vem há al- 
guns anos, produzindo comercialmente, por um processo não especificado, farelo de mamona destoxicado denominado Lex Proteico. Este produto tem sido empregado com bom resultado na alimentaçäo de animais.

Em 1966, SEVKOVIC et alii relataram os resulta dos de experimentos onde farelo de mamona foi utilizado na alimentação de diversas espécies animais. Nenhum sintoma ou $\underline{e}$ feito patológico foi observado em ratos ou cobaias que recobe ram $20 \%$ da torta nas raçōes, durante dois meses. Até 2008 diárias ou $20 \%$ do concentrado foram utilizados por porcos em acabamento, sem problema algum.

KHAN et alii, em 1968, analisaram o farelo de mamona e, pelos resultados obtidos, afirmaram que era altamen te nutritivo. Esses autores trabalharam com farelo provenien te de sementes sem casca e os resultados percentuais da enálí so química foram: proteína bruta, 56,0 ; matéria mineral, 8,1; matéria fibrosa, 2,0 e material tóxico, 3,5 .

- farelo de mamona destoxicado, de acordo com VIIHJAIMSDOTTIR e FISHER (1971), pode ser usado como fonte de proteína para frangos de corte e também para outros monogástricos.

Em 1972, NUNES, substituindo o farelo de soja pelo de mamona destoxicado, em níveis crescentes de 0 a $12 \%$ na ração de suinos, observou que: 1) o farelo de mamona pode substituir até $50 \%$ da parte proteica da dieta de suínos com ganho de peso igual 20 da testemunha e com menos custo por quilo de peso ganho; 2) năo foi observado quadro tóxico ou alérgico em nenhum animal; 3) o exame anátomo-patológico das vísceras (rins e fígado) revelou apenas pequenas alterações, comuns a todos os tratamentos.

De acordo com BRAGA et alii (1973), alimentando coelhas durante 21 meses com rações contendo $23,30 \%$ de mamona destoxicada, não encontraran al teraçōes na reprodutividą 
de, comparando-as com outras coelhas alimentadas com farelo de babaçu.

POIIT e SGARBIERI, em 1976, eliminaram a toxidez do farelo de mamona e, analisando sua composição en amino ácidos, verificaran que é deficiente em lisina, metionina e cistina. Alimentando ratos com o farelo destoxicado, conclui ram que o consumo alimentar e o estado sanitário dos animais, no final do experimento, foram satisfatórios.

\subsection{Farelo de mamona destoxicado na alimentacão de aves}

Em 1949, BORCHERS realizou vários experimentos com o farelo de mamona na alimentação de aves. Concluiu ser extremamente tóxico quando ingerido pelas aves sem haver sofrido nenhum processo de destoxicação. Após completa destoxí cação, substituiu $10 \%$ de uma raçāo controle para aves e o ganho de peso e mortalidade das aves não foram estatisticamente diferentes aos da ração controle.

KUMANOV e VOLCHEV, em 1954, alimentando galinhas da raça Rhode Island, com mais de um ano de Idade, com ra ções contendo $20 \%$ de farelo de mamona, verificaram que a produção de ovos foi reduzida durante seis semanas, em comparação com a de aves que receberam outras três diferentes rações. Essas diferentes rações eram compostas, cada uma, de $20 \%$ de farelo de girassol, farelo de linhaça e farelo de semente de uva, respectivamente.

Estudando os efeitos da substituição da protel na de origem animal, pela proteína do farelo de mamona, nas rações de poedeiras, EYBIMA em 1958, concluiu que tanto na fa se de crescimento como na de postura, os alimentos de origem animal poden ser substituidos pelo farelo de mamona. Esse au tor não encontrou diferença significativa entre a produção e o peso médio dos ovos das aves que receberam os dois tipos de alimentos. 
De acordo com RATMO (1958), POLIAKOFF (1960) e RAYMOND (1961), a utilização do farelo de mamona destoxicado na alimentação de aves, até o nível de $15 \%$, apresentou resultados de crescimento e mortalidade satisfatórios. A partir desse nivel, o crescimento foi retardado e ao nível de $30 \%$ das raçōes, a mortalidade foi muito elevada. Os autores atrí buiram esses fatos à ação prejudicial do excesso de fibras e uma intoxicação progressiva.

Em 1961, COSTA e LAUN, empregando farelo de ma mona destoxicado na alimentação de pintos machos das raças Leghorn branca e New Hampshire, concluiram que o farelo é uma boa fonte de proteínas, podendo substituir parcialmente nas rações, as proteínas da soja e do amendoim. Estes autores afirmaram ainda, que o produto é altamente eficiente quando em pregado até $10 \%$ das rações.

Utilizando o farelo na alimentação de poedeiras, em 1962, LAUN e COSTA concluiram que näo é aconselhável sua inclusão em raçōes para poedeiras, provavelmente devido ao seu elevado teor en fibras. Verificaram que mesmo com somente $5 \%$ do farelo nas raçōes, a postura foi sensivelmente in ferior à ração padrão, embora 0 uso do farelo de mamona näo tiresse resultado em diminuiçāo do peso vivo das galinhas ao fin do experimento.

RAIMO, citado por IOUREIRO em 1962, concluiu que o farelo de mamona destoxicado tem como 1 imite $15 \%$ dos alimentos de boa qualidade, para pintos até 12 dias de idade.

Em 1963, FUNATSU et alii, alimentando frangos com o farelo destoxicado, durante oito semanas, concluiram que, mesmo se pequena quantidade de alérgeno continuasse presente no farelo, näo ocasionaria nenhum dano às aves. Afirmaram que se fosse empregado um método apropriado de eliminar a ricina, o farelo poderia ser utilizado na alimentaçäo animal. 
Estudando os efeitos da utilização do farelo destoxicado nos níveis de 2,5 e $5 \%$ nas rações de frangos e poedeiras, em 1963, OKAMOTO et alii relataram que nenhun sintoma de intoxicação foi observado nos frangos com sete dias de idade. Foram observados distúrbios na produção de ovos de galinhas que receberam ração com .5\% do farelo. Os mesmos autores, em 1965, utilizando o farelo em diferentes níveis, até - máximo de $40 \%$ nas rações de frangos e poedeiras, verificaram que houve retardamento no crescimento dos frangos quando - farelo foi usado nos níveis de 5 e $10 \%$, até a 7 a semana de idade. Nas poedeiras năo foi observado efeito negativo na produçāo de ovos, nesses mesmos níveis. Os autores concluiram que o retardamento no crescimento dos frangos foi devido à baixa digestibilidade do farelo, apesar da sua excelente composição em aminoácidos, e não à ação tóxica de algum princípio.

Em 1966, MURASE et alii, após eliminarem completamente a ricina do farelo de mamona, utilizaram o produto na alimentação de frangos e poedeiras, e obtiveram ótimos resultados quando o teor do farelo era de 5\% da ração. Quando - farelo foi utilizado no nível de $40 \%$ na ração, foi observada açāo tóxica que posteriormente ficou provado ser ocasionada pela ricinina que estava presente no farelo ao nivel de $0,13 \%$.

Utilizando raçōes com $0,4,8$ e $12 \%$ de farelo de mamona destoxicado, o qual substituiu parcialmente 0 concentrado comercial em rações de frango de corte, GADELHA et alii, em 1969, concluiram que a eficiência alimentar aumentou proporcionalmente com o aumento do farelo de mamona até o nível de $8 \%$. Daí por diante, decresceu. 0 consumo de raçäo não foi estatisticamente diferente para os niveis de $0,4 \mathrm{e}$ 8\%. - custo de produção da ração com $8 \%$ de farelo foi $13 \%$ in ferior ao da ração que não continha o farelo. o conteúdo de 
fibra bruta na ração con $12 \%$ de farelo era 1,7 vezes maior que o dos outros tratamentos, sendo provavelmente um dos fato res responsáveis pela baixa eficiência alimentar desse tratamento.

Alimentando pintos de um até vinte e un dias de idade, dos dois sexos, com farelo de mamona destoxicado, em 1971, VILHJAIMSDOTIIR e FISHER concluiram que o baixo valor biológico do farelo era devido à sua eficiência em lisina, triptofano, metionina e cistina. Quando o farelo foi suplementado com esses aminoácidos, promovev o crescimento normal das ares, comparável ao da ração testemunha. Os aminoáci dos limitantes do farelo foram a lisina e o triptofano, respectivamente, 19 e 2\%. O farelo utilizado nas raçoes continha $15 \%$ de fibra e esse nivel, relativamente alto, foi respon sável por um aumento de $20 \%$ do consumo alimentar comparado ao da ração testemunha. Se a fibra for total ou parcialmente re tirada do farelo, poderá aumentar seu emprego como fonte de proteina para monogástricos.

En 1971, FULLER et alii concluiram que o farem 10 destoxicado deve ser limitado até o nivel de aproximadamen te 10 a $15 \%$ das rações de frangos. Afirmaram, ainda, que em raçōes para poedeiras sua utilizaçäo seria mais proveitosa.

GADELEA et alii, em 2973, substituindo $0,4,8$ - $12 \%$ do farelo de soja de rações comerciais por igual percen tagem de farelo de mamona destoxicado e, alimentando pintos de um dia até 42 dias de idade, verificaram que à medida que - nivel de farelo de mamona foi aumentado na ração, o consumo alimentar o gano de peso das aves diminuiram. Os autores suspeitara da possibilidade da destruição de certos aminoácì dos durante o processo de industrialização, pois em trabalho realizado em 1969, os mesmos autores obtiveram conversão alimentar melhor que a da testemunha, quando a utilização do farelo foi feita atẻ o nivel de $8 \%$ na ração. 
Fm 1976, CARVALHO et alii estudaram os efeitos de diferentes níveis de farelo de mamona destoxicado na alimentação de poedeiras, após atingirem o quarto mês de produção. Para verificar o efeito que o farelo poderia exercer so bre a produção de ovos foram utilizadas cinco rações, onde 0 farelo substituin iguais teores de uma mistura de farelo de soja e farelo de trigo, de modo a manter as rações isoproteicas. Os niveis de substituição foram $0,2,5,5,7,5$ e $10 \%$. Analisando, no final do experimento, os resultados para morta lidade, conversão alimentar e produção e peso médio dos oros, os autores observaram não haver diferença significativa entre tratamentos para os resultados referentes à mortalidade e con versão alimentar. Para os dados de produção de ovos, os níveis de 0,5 e $10 \%$ do farelo não diferiram estatisticamente entre si. No tocante a peso médio dos ovos, o tratamento que näo continß̧a mamona foi superior aos demais, diferindo significativamente. Os demais tratamentos nāo diferiram estatisti camente entre si. Bseados nesses resultados, os autores concluiram que a utilização do farelo de mamona destoxicado em rações para poedeiras, está na dependência econômica, a qual poderá ocorrer com a diminuição do custo das raçōes, quando se usas o farelo como fonte auxiliar de proteina.

\subsection{Poder laxativo do óleo de mamona}

o óleo de mamona também chanado óleo de rícino, é empregado há muito tempo em medicina, segundo ATMEIDA (2950), en virtude de suas propriedades purgativas, as quais são devidas ao ácido ricinoleico. No intestino, o óleo de rí cino é emulsionado e se decompőe parcialmente em ácido ricing leico livre e glicerina. o ácido livre tem a propriedade de irritar a mucosa intestinal e a esta ação irritante é que se deve o poder laxativo do bleo de rícino. A parte do óleo que fica sem se decompor, lubrifica as massas fecais e a mucosa do intestino, favorecendo desse modo, a ação purgativa. 
ROYER \& MAZURE (1951) e ROYER A MAZURE (1952) demonstraram que fornecendo óleo de rícino a humanos, ocasionox elevada aceleração na velocidade de passagem do quimo através dos intestinos.

De acordo com BALBACHAS (1959), a dose de óleo usada como purgativo para um adulto, é de duas colheres de so pa.

Em trabalho realizado com pombos, IECOQ em 1942, mostrou que rações contendo alto nivel de óleo de mamona podem tornar-se desbalanceadas em virtude do efeito laxati vo do olleo. Os pombos utilizados pelo autor en seu trabalho, chegaram a apresentar sintomas de avitaminose $B_{1}$ ou polineuri te.

Em 1947, JONES fazendo uma revisão sobre o uso do farelo de mamona na alimentação animal, afirmon que o óleo residual, presente no farelo, pode afetar o desenvolvimento dos animais. Apesar de o processo industrial retirar a maior parte, ainda resta no farelo aproximadamente $1 \%$ de óleo. Se pequenas quantidades de óleo forem ingeridas, durante um período prolongado, podem surgir efeitos prejudiciais aos animais.

REYNELLI e SPRAY (1958) relataram que o óleo de mamona fornecido a ratos ocasionou rápida evacuação do baixo íleo dos animais. Em 1975, AWOUTERs et alii descreveram diax réia en ratos que ingeriram $\mathrm{l} \mathrm{ml}$ de óleo de mamona.

ROSEATBERG (1953) acha que o uso de substâncias com poder laxativo, ocasiona a ineficiência das racoōes, fazen do com que haja desperdicio de nutrientes, eliminados parcial mente digeridos.

De acordo com JHNKINS (1963), a presença do o100 na torta de mamona näo parece ser prejudicial. o efeito purgativo do óleo foi atribuído ao fato de que, ingerido sozi 
nho, não pode ser perfeitamente emulsificado no intestino e, portanto, não $\dot{\theta}$ absorvido.

Experimentalmente, 0 efeito laxativo de substâncias alimentares tem sido determinado pela umidade das fezes.

\section{Segundo OSER (1965), a ingestão pelo animal,} de substâncias com propriedades lazativas, sendo relativamente indigeríveis, absorvem rapidamente água. Deste modo, ocasionan a formação de massa fecal volumosa, que sendo bastante mole, permite rápida evacuação. 0 mesmo autor afirma ainda que excesso de óleos nảo absorvíveis podem interferir na absorção de vitaminas lipossolúveis.

FULIER et alii, em 1971, estudando o efeito da atilizaçäo do farelo de mamona destoxicado na alimentaçāo ani mal, afirmaram que um problema básico para sua utilização é a possivel ação do óleo residual presente no farelo, que poderá afetar 0 desempenho dos animais. 
4. MATERIAL E METODOS

\subsection{Instalações e equipamentos.}

O experimento foi realizado nas instalações do CEPA (Centro de Experimentação e Pesquisa Anhanguera), perten cente ao Departamento Técnico da Raçöes Anhanguera S.A., 10ca lizadas no Município de Jarinu, Estado de São Paulo, cuja altitude é de 743 metros, longitude WG de $46^{\circ} 44^{\prime}$ e latitude sul de $23^{\circ} 06^{\circ}$.

- galpão experimental está disposto na orienta ção leste-oeste, com as seguintes dimensōes: $10,0 \mathrm{~m}$ de 1 argura, 65, 0m de comprimento e $3,0 \mathrm{~m}$ de pé-direito. A cobertura é de cimento anianto, com lanternim central ao longo de todo o galpão. Na parte central do prédio, está localizado o pintej ro, separado dos dois frangueiros por duas áreas de serviço. As paredes laterais de concreto medem $0,30 \mathrm{~m}$ de al tura e acima delas se estende uma tela de arame com malhas de duas polegadas. Da merma maneira sāo as paredes das divisões internas. Tanto a face leste quanto a oeste, são fechadas completamente por paredes de alvenaria, o mesmo ocorrendo com as paredes que separam as áreas de serviço localizadas entre o pinteiro e os frangueiros. 
o pinteiro possui 12 dirisões de cada lado de un corredor central de $1,60 \mathrm{~m}$ de largura. Cada divisão mede $2,58 \mathrm{~m} \times 1,10 \mathrm{~m}\left(2,86 \mathrm{~m}^{2}\right)$, com as portas abrindo-se para o corre dor central.

A "cama" utilizada foi de cavaco de madeira, tanto no pinteiro como no frangueiro.

o equipamento utilizado em cada divisảo do pin teiro foi o seguinte: uma caixa de madeira para ração, com ca pacidade aproximada para 30kg; um comedouro tipo bandeja, de $0,60 \mathrm{~m} \times 0,40 \mathrm{~m}$, utilizado até 0 quinto dia de vida dos pintos; dois comedouros tipo cocho, de madeira, medindo $0,95 \mathrm{~m}$, utilizados a partir do quinto dia de vida dos pintos; un bebedouro de pressão, com capacidade para dois litros, utilizado até • décimo dia de vida cos pintos; um bebedouro tipo calha, de 2,58m de comprimento, de metal esmaltado, com água corrente, localizado junto à parede exterma do galpão; uma campânula a gás, para aquecimento dos pintos até o décimo dia de idade.

o pinteiro é fechado lateralmente por esquadrias basculantes, que têm as aberturas controladas de acordo com a necessidade.

A iluminação do pinteiro é feita por quatro lâmpadas incandescentes de 60 , distribuidas ao longo do corredor central, a uma altura de $3,0 \mathrm{~m}$.

No centro do pinteiro e junto ao corredor central, foram colocados: um termômetro para medição de temperatura máxima e mínima e um higrômetro, para a medição da umida de relativa do ar. Durante os 10 primeiros dias, quando as campânulas permaneceram ligadas, as anotações de temperatura e umidade relativa foram feitas de hora em hora. Durante este período, procurou-se manter a temperatura das divisões internas, a mais uniforme possivel, através da regulagem da altura das campannulas e aberturas das esquadrias. A partir do 110 dia de vida dos pintos, as anotações foram feitas seis ve 
zes ao dia. Un resumo dos valores médios de temperatura e umidade aparece na Tabela 30 , no apêndice.

O frangueiro utilizado foi o da extremidade 1este. Possui, também, 12 divisōes de cada lado de um corredor central de $1,60 \mathrm{~m}$ de largura. Cada divisão mede $2,58 \mathrm{~m} x$ $1,80 \mathrm{~m}\left(4,64 \mathrm{~m}^{2}\right)$, com as portas se abrindo para o corredor.

- equipamento utilizado em cada divisão do frangueiro foi o seguinte: uma caixa de madeira para raçāo, com capacidade para 30kg; dois comedouros tipo cocho, de madeira, de altura regulável e com 0,95 m de comprimento cada; un bebedouro tipo calha, de 2,58m de comprimento, de ferro es maltado, com água corrente, localizado junto à parede externa do galpāo.

Junto às telas laterais do frangueiro, havia cortinas de plástico, que se fechavam de baixo para cima.

A iluminação do frangueiro era feita por seis lâmpadas incandescentes de $60 \mathrm{w}$ cada, distribuidas ao longo do corredor central a $3,0 \mathrm{~m}$ de altura.

\subsection{Períodos de criação}

O experimento foi dividido em duas fases: Inicial e final. A fase inicial compreendeu o periodo do 1920 350 dia de idade, com inicio no dia $08 / 4 / 77$ e témino no dia 12/5/77. A fase final foi do 360 ao 569 dia de idade, con início no dia $13 / 5 / 77$ e término no dia $02 / 6 / 77$.

\subsection{Delinearnento experimental}

O delineamento experimental foi o de blocos ca sualizados, com seis tratamentos e quatro repetiçōes, perfazendo 24 unidades experimentais ou parcelas. Fn cada unidade experimental foran distribuidas 36 aves, sendo 18 machos e 18 rềmeas, totalizando assim 864 aves experimentais. 0 esquema 
da análise de variância, com decomposição da soma de quadrados de tratamento nos componentes de regressão polinomial até - 50 grau, conforme mostra GOMES (1976), foi o seguinte:

\begin{tabular}{lllll}
\hline Fonte de variação & G.L. & S.Q. & Q.M. & F \\
\hline
\end{tabular}

Regressão linear I

Regressão quadrática 1

Regressão cúbica 1

Regressão 40 grau 1

Regressão 50 grau 1

(Tratamentos) (5)

Blocos 3

Resíduo 15

Total 23

Os tratamentos foram distribuídos por sorteio, dentro de cada bloco, e eram constituídos por diferentes raçöes, onde houve substituição parcial da proteína do farelo de soja pela proteína do farelo de mamona destoxicada, obedecendo os seguintes critérios: 
Tratamentos

\begin{tabular}{l} 
C \\
\hline$A$ \\
$B$ \\
$C$ \\
$D$ \\
$E$ \\
$F$
\end{tabular}

$$
\text { troteina do }
$$$$
\text { farelo de soja }
$$

$(\%)$

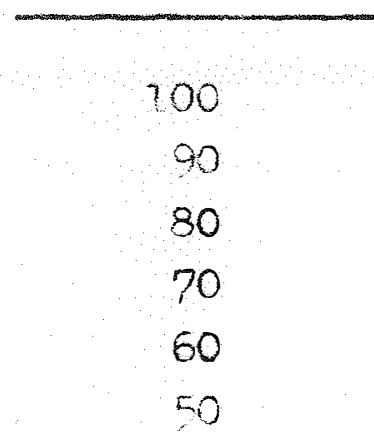

Proteina do farelo de mamona destoxicado

(\%)

4.4. Aves experimentais,

Foram utilizados 864 pintos de um dia ( 432 machos e 432 fêmeas) da linhagem "Peterson", provenientes da Granja Rezende S.A., Uberländia, Estado de Minas Gerais. Os pintos chegaram em estado satisfatório, bastante uniformes e já separados por sexo, através de sexagem pela asa. 0 peso médio destes pintos, obtido no local do ensaio, foi de 42,0 gramas.

\subsection{Manejo das aves.}

Logo após a chegada na granja, os pintos passa ram por uma seleção, pesagem individual e identificação através de placas colocadas nas asas. Em seguida, foram soltos em grupos de 18 machos e 18 fêmeas, em cada divisâo do pinteí ro. Esta divisão havia sido previamente aquecida através de uma campânula à gás e que permaneceu ligada até o 100 dia de vida dos pintos.

A lotação era de 12,6 aves $/ \mathrm{m}^{2}$ de piso até 21

dias de idade, quando as aves foram transportadas para o fran gueiro. 
Durante o primeiro dia, as aves receberam água com $2,0 \%$ de açucar. Antes de serem soltas, tiveram o bico me Ihado individualmente na solução de açủcar.

Os bebedouros de pressão permaneceram no galpão até o 100 dia de idade e foram lavados três vezes ao dia. A partir do 80 dia, a água era oferecida também em bebedouros tipo calha, que também foram lavados três vezes ao dia.

Os comedouros tipo bandeja foram utilizados até 050 dia de vida dos pintos, e eram abastecidos de ração várias vezes por dia. Do 50 dia em diante, foram utilizados dois comedouros tipo cocho, de madeira, em cada divisāo. A ração era distribuida quatro ou mais vezes 20 dia, de modo a fornecer ração à vontade às aves, mas não ultrapassando nunca $1 / 3$ da capacidade dos comedouros.

No 30 dia do experimento, foi feita a homoge"neização dos pintos, através de observação visual cuidadosa em todas as parcelas do experimento. Os pintos fracos e mal desenvolvidos foram substituídos por outros do mesmo sexo, mas de boa qualidade. Para isto, os pintos que sobraram da seleção do 10 dia, foram mantidos em bateria aquecida, recebendo todos a ração testemunha.

Até 030 dia, foram também substituidos todos - os pintos que morreram, de modo que a contagem da mortalidade teve inicio após o 30 dia de rida dos pintos.

No 210 dia de vida, as aves foram transportadas para o frangueiro, onde permaneceram até o término do experimento.

A partir da 2 a semana, as aves foram semanalmente pesadas. Na 2a, 4a, 6a e 7 a semana, as pesagens foram coletivas. Ha $3 \underline{a}, 5$ a 8 a semana, as pesagens foram individuais. A pesagem era feita sempre de manhã. Tanto para a pe sagem inicial dos pintos, como para as demais pesagens indivi 
duais, foi utilizada uma balança com capacidade para $6,0 \mathrm{~kg}$ e com precisão de 5,0 gramas. As pesagens coletivas foram feitas em balança com capacidade para $300,0 \mathrm{~kg}$ e com precisão de 100,0 gramas.

As aves foram vacinadas contra a doença de New Castle no 100 e 300 dia de vida, na água de bebida.

A partir do 210 dia de vida das aves, foran feitas semanalmente, colheitas de fezes para a verificação da possivel presença de oocistos de Eimerias e ovos de vermes.

A partir da 5a semana de vida, a "cama" de todas as parcelas foi revolvida duas vezes por semana.

As aves receberam iluminação continua 24 horas por dia, durante todo o período de criação. Durante o dia, a iluminaçāo era natural, enquanto que à noite, era dada por lâmpadas incandescentes, que permaneciam ligadas, do por ao nascer do sol.

\subsection{Raçôes experimentais}

Os ingredientes utilizados para a formulação das rações foram analisados no Laboratório de Controle de qua lidade da Raçōes Anhanguera S.A., em Campinas, Estado de São Paulo, segundo as técnicas recomendadas pelo A.O.A.C. (1975) e A.0.C.S. (1967). As rações foram balanceadas segundo as eXigências apresentadas por scotT et alii (1969). Os aditivos tais como: coccidiostático, antibiótico, antioxidante e estimulante de crescimento, foram adicionados às raçōes conforme as recomendações dos fabricantes.

As rações foram elaboradas no setor do CEPA, \localizado no recinto da Fábrica de Rações Anhanguera S.A., tell Campinas, utilizando-se matérias primas previamente anali- sadas. Foram colhidas amostras de todas as rações e enviadas ao laboratório acima citado, para análises físicas e químicas. 
Na Tabela 5, aparece a composição química bromatológica dos ingredientes utilizados na elaboração das rações.

$\mathrm{Na}$ Tabela 6 , aparece 0 aminograma dos ingredientes utilizados na elaboração das rações, determinado em um auto-analisador (Beckman - Automatic Amino Acid Analizer - mo delo 129), através de hidrólise ácida da amostra.

Na Tabela 7, aparecem a composição percentual das raçōes iniciais. Estas raçōes foram fornecidas até 0359 dia de vida das aves.

Na Tabela 8, aparece a composição química bromatológica calculada das raçōes iniciais e, na Tabela 9 , 0 aminograma calculado das mesmas.

0 premix utilizado para a fase inicial, com ex ceção da I-Iisina e DL-Metionina, tinha a mesma composição em todos os tratamentos e forneceram os seguintes niveis de vita minas, minerais e aditivos, por quilo de ração:

Vitamina A, 11.000 UI

Vitamina $\mathrm{D}_{3}, 1.000 \mathrm{UI}$

Vitamina E, 15,00 mg

Vitamina $\mathrm{K}_{3}, 2,16 \mathrm{mg}$

Vitamina $B_{1}, 2,25 \mathrm{mg}$

Vitamina $\mathrm{B}_{2}, 4,41 \mathrm{mg}$

Vìtamina $B_{12}, 10,50 \mathrm{mcg}$

Hiacina, $33,00 \mathrm{mg}$

Acido pantotênico, 14,30 mg

Colina, $345,00 \mathrm{mg}$
Manganês, 81,75 mg

Ferro, $26,50 \mathrm{mg}$

Zinco, 25,00 mg

Cobre, 2,92 mg

Cobalto, $1,60 \mathrm{mg}$

Iodo, $1,57 \mathrm{mg}$

Monensina sódica, 100,00 mg

Bacitracina de zinco, 10,00mg

Etoxiquim, 125,00 mg

Farelo de trigo, q.s.p.,

$9.000,00 \mathrm{mg}$

A L-Lisina e a DI-Metionina foram adicionadas a. premix, de modo a fornecer $1.153 \mathrm{mg}$ e $465 \mathrm{mg}$, respectivamente, por quilo de ração. 


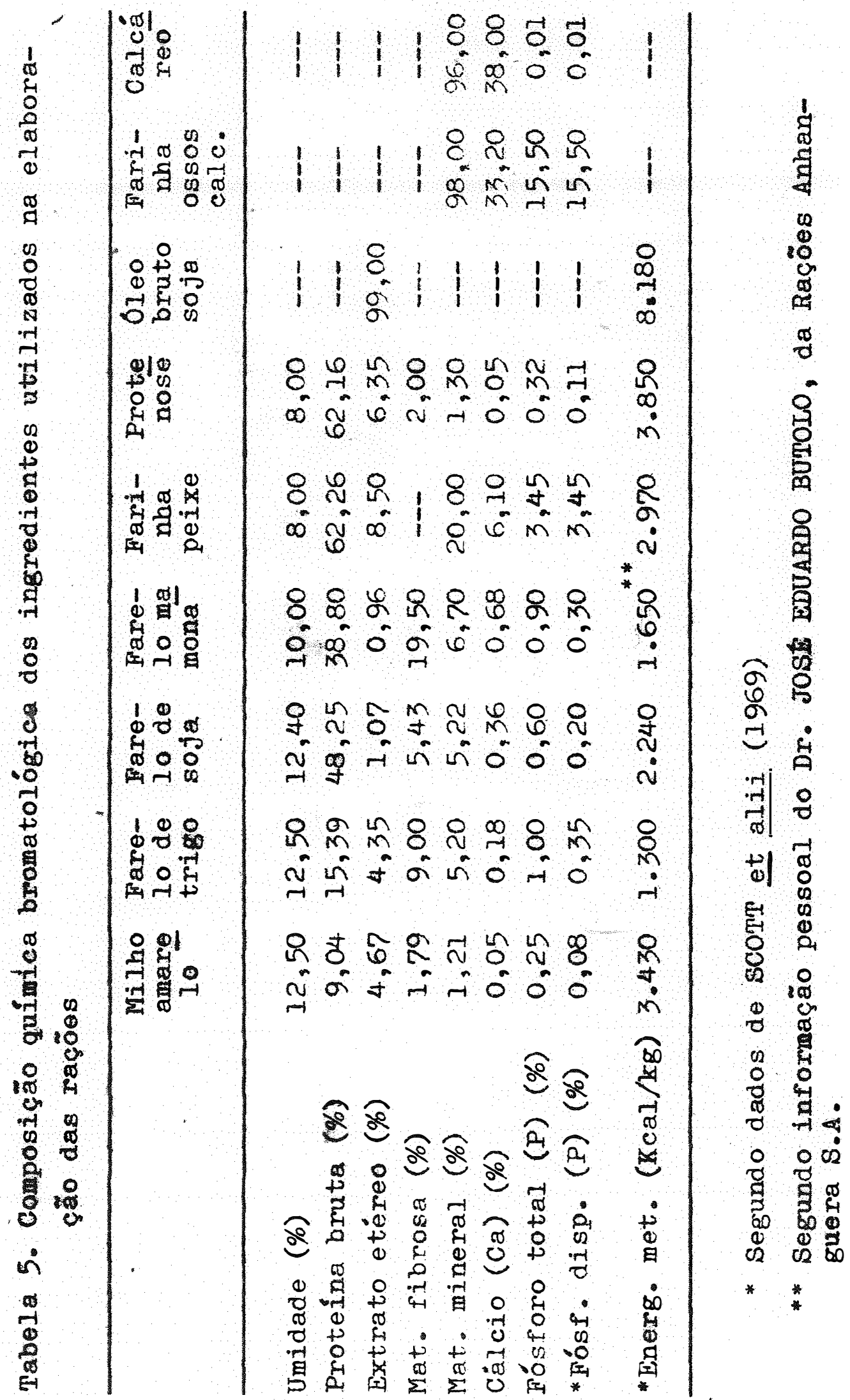


Tabela 6. Aminograma dos ingredientes utilizados na elaboração das rações (em $\mathrm{g} / 100 \mathrm{~g}$ de amostra).

\begin{tabular}{|c|c|c|c|c|c|c|}
\hline Aminoácidos & $\begin{array}{c}\text { Milho } \\
\text { amare } \\
10\end{array}$ & $\begin{array}{l}\text { Fare } \\
10 \text { de } \\
\text { trigo }\end{array}$ & $\begin{array}{l}\text { Fare- } \\
10 \text { de } \\
\text { soja }\end{array}$ & $\begin{array}{l}\text { Fare - } \\
10 \mathrm{ma} \\
\text { mona }\end{array}$ & $\begin{array}{c}\text { Tari- } \\
\text { nha } \\
\text { peixe }\end{array}$ & $\begin{array}{l}\text { Prote } \\
\text { nose }\end{array}$ \\
\hline
\end{tabular}

Ac. aspártico $\quad 0,688 \quad 1,200 \quad 5,530 \quad \cdots \quad 5,960 \quad 4,140$ Ac. glutâmico $\quad 1,860 \quad 2,750 \quad 7,730 \quad \cdots \quad 7,720 \quad 13,670$ Alanina $\quad 0,673 \quad 0,730 \quad 1,940 \quad \cdots \quad 3,900 \quad 5,780$ $\begin{array}{lllllll}\text { Arginina } & 0,468 & 1,110 & 3,240 & 2,880 & 3,600 & 1,970\end{array}$ $\begin{array}{lllllll}\text { Cistina } & 0,191 & 0,350 & 0,840 & 0,394 & 0,570 & 1,150\end{array}$ Fenilalanina $\quad 0,462 \quad 0,600 \quad 2,280 \quad 1,300 \quad 2,330 \quad 3,870$ Glicina $\quad \begin{array}{lllllll}0,405 & 0,820 & 1,990 & 1,430 & 5,030 & 1,730\end{array}$ Histidina $\begin{array}{llllll}0,282 & 0,440 & 1,020 & 0,532 & 1,693 & 1,320\end{array}$ $\begin{array}{lllllll}\text { Isoleucina } & 0,344 & 0,480 & 2,060 & 1,480 & 2,410 & 2,630\end{array}$ $\begin{array}{lllllll}\text { Leucina } & 1,089 & 0,920 & 3,390 & 2,200 & 4,240 & 10,490\end{array}$ Iisina $\quad \begin{array}{lllllll}0,307 & 0,630 & 2,640 & 0,740 & 4,520 & 1,020\end{array}$ $\begin{array}{lllllll}\text { Metionina } & 0,139 & 0,220 & 0,610 & 0,430 & 1,570 & 1,580\end{array}$ Prolina $\quad 0,832 \quad 0,880 \quad 1,930 \quad \cdots \quad 3,220 \quad 6,050$ Serina $\begin{array}{llllll}0,458 & 0,640 & 2,320 & 1,690 & 2,370 & 3,320\end{array}$ $\begin{array}{lllllll}\text { Tirosina } & 0,220 & 0,540 & 1,300 & 0,855 & 2,257 & 3,440\end{array}$ $\begin{array}{lllllll}\text { Treonina } & 0,346 & 0,500 & 1,730 & 1,180 & 2,420 & 2,170\end{array}$ $\begin{array}{lllllll}\text { Triptofano } & 0,090 & 0,240 & 0,573 & 0,313 & 0,685 & 0,300\end{array}$ Valina $\quad 0,555 \quad 0,730 \quad 2,170 \quad 2,180 \quad 3,000 \quad 3,000$ 
Tabela 7. Composição percentual das raçōes iniciais

$$
\text { Ir a t a me ntos }
$$

Ingredientes

A $\begin{array}{llllll} & B & C & D & E & \text { I }\end{array}$

$\begin{array}{lrrrrrr}\text { Milho anarelo } & 55,10 & 55,10 & 55,10 & 55,33 & 55,33 & 55,33 \\ \text { Farelo trigo } & 5,96 & 4,81 & 3,65 & 2,31 & 1,16 & -- \\ \text { Parinha peixe } & 2,00 & 2,00 & 2,00 & 2,00 & 2,00 & 2,00 \\ \text { Protenose } & - & 0,30 & 0,60 & 0,90 & 1,20 & 1,50 \\ \text { Oleo br. soja } & 2,40 & 2,50 & 2,60 & 2,70 & 2,80 & 2,90 \\ \text { Farelo de soja } & 31,09 & 27,98 & 24,87 & 21,76 & 18,65 & 15,54 \\ \text { Farelo mamona } & --- & 3,86 & 7,73 & 11,60 & 15,46 & 19,33 \\ \text { Calcáreo } & 1,55 & 1,55 & 1,55 & 1,55 & 1,55 & 1,55 \\ \text { Parinha ossos } & 0,70 & 0,70 & 0,70 & 0,65 & 0,65 & 0,65 \\ \text { Sal iodizado } & 0,30 & 0,30 & 0,30 & 0,30 & 0,30 & 0,30 \\ \text { Premix } & 0,90 & 0,90 & 0,90 & 0,90 & 0,90 & 0,90\end{array}$


Tabela 8. Composição química bromatológica calculada das rações iniciais.

\begin{tabular}{|c|c|c|c|c|c|}
\hline A & B & c & $D$ & $\mathbf{E}$ & $P$ \\
\hline
\end{tabular}

Prot. bruta \% 22,19 22,20 22,20 22,21 $22,22 \quad 22,22$ $\begin{array}{lllllll}\text { Ext. etèreo } \% \quad 5,72 & 5,80 & 5,86 & 5,93 & 6,01 & 6,09\end{array}$ $\begin{array}{lllllll}\text { Mat. fibrosa } \% \quad 3,23 & 3,71 & 4,20 & 4,67 & 5,14 & 5,64\end{array}$ $\begin{array}{lllllll}\text { Mat. mineral } \% \quad 5,46 & 5,50 \quad 5,54 & 5,52 \quad 5,57 & 5,61\end{array}$ $\begin{array}{llllllll}\text { Cálcio (Ca) } \% & 1,09 & 1,11 & 1,12 & 1,12 & 1,13 & 1,14\end{array}$ $\begin{array}{lllllllll}\text { Fósf.tot.(P) } & \% & 0,56 & 0,57 & 0,57 & 0,57 & 0,58 & 0,58\end{array}$ $\begin{array}{lllllll}\text { Fósf.disp.(P) } \% & 0,32 & 0,32 & 0,32 & 0,31 & 0,31 & 0,32\end{array}$ Energia metabo $\begin{array}{lllllll}\text { lizável } \mathrm{Kcal} / \mathrm{Kg} & 2.932 & 2.934 & 2.931 & 2.935 & 2.934 & 2.933\end{array}$ 
Tabela 9. Aminograma calculado das rações iniciais (g/100g de amostra).

$$
\text { T r a t a m e n t o s }
$$

Aminoácidos

A

B

c

D

$E$

F

$\begin{array}{lllllll}\text { Arginina } & 1,403 & 1,407 & 1,412 & 1,414 & 1,417 & 1,421 \\ \text { Cistina } & 0,398 & 0,386 & 0,375 & 0,364 & 0,353 & 0,341 \\ \text { Fenilalanina } & 1,047 & 1,031 & 1,014 & 0,999 & 0,982 & 0,966 \\ \text { Glicina } & 0,985 & 0,974 & 0,965 & 0,955 & 0,944 & 0,933 \\ \text { Histidina } & 0,532 & 0,520 & 0,508 & 0,496 & 0,483 & 0,472 \\ \text { Isoleucina } & 0,907 & 0,902 & 0,898 & 0,893 & 0,889 & 0,883 \\ \text { Leucina } & 1,794 & 1,794 & 1,795 & 1,796 & 1,797 & 1,797 \\ \text { Lisina } & 1,155 & 1,154 & 1,153 & 1,152 & 1,151 & 1,149 \\ \text { Metionina } & 0,463 & 0,463 & 0,463 & 0,465 & 0,476 & 0,487 \\ \text { Tirosina } & 0,602 & 0,599 & 0,596 & 0,592 & 0,588 & 0,586 \\ \text { Treonina } & 0,807 & 0,800 & 0,791 & 0,784 & 0,776 & 0,769 \\ \text { Triptofano } & 0,256 & 0,249 & 0,242 & 0,234 & 0,226 & 0,219 \\ \text { Valina } & 1,085 & 1,101 & 1,120 & 1,136 & 1,153 & 1,170\end{array}$


Na Tabela 10, aparece a composição percentual das raçōes finais. Estas raçōes foram fornecidas do 369 ao 560 dia de vida das ares, quando o experimento foi encerrado.

Na Tabela 11, aparece a composição química bro nátológica calculada das raçōes iniciais e na Tabela 12, o aminograma calculado das mesmas.

o premix utilizado para a fase final, com exce ção da L-Iisina e DL-Metionina, tinha a mesma composição em todos os tratamentos e forneceu os seguintes níveis de vitami nas, minerais e aditivos, por quilo de ração:

Vitamina A, $3.500 \mathrm{UI}$

Vitamina $\mathrm{D}_{3}, 800 \mathrm{UI}$

Vitamina $E, 15,00 \mathrm{mg}$

Vitamina $\mathrm{K}_{3}, 2,34 \mathrm{mg}$

Vitamina $B_{1}, 2,35 \mathrm{mg}$

Vitamina $\mathrm{B}_{2}, 4,31 \mathrm{mg}$

Vitamina $\mathrm{B}_{12}, 7,00 \mathrm{mcg}$

Niacina, $33,00 \mathrm{mg}$

Acido pantotênico, $9,52 \mathrm{mg}$

Colina, 258,72 mg
Manganês, 81,75 mg

Ferro, $26,50 \mathrm{mg}$

Zinco, 25,00 mg

Cobre, 2,9? mg

Cobalto, 1,60 mg

Iodo, 1,57 mg

Monensina sódica, 100,00 mg

Bacitracina de zinco, 10,00 mg

Etoxiquim, $125,00 \mathrm{mg}$

Farelo trigo, q.s.p., ?.000 mg

A I-Lisina e a DI-Metionina foram adicionadas ao premix de modo a fornecer $973 \mathrm{mg}$ e $392 \mathrm{mg}$, respectivamente, por quilo de ração. 
Tabela 10. Composição percentual das rações finais

$$
\text { Trat a m e n t os }
$$

Ingredientes

\begin{tabular}{|c|c|c|c|c|c|}
\hline A & B & $C$ & $D$ & $E$ & $F$ \\
\hline
\end{tabular}

Milho amarelo $\quad 63,75 \quad 64,00 \quad 64,25 \quad 64,50 \quad 64,70 \quad 64,90$

Farelo trigo $\quad 7,83 \quad 6,87 \quad 5,92 \quad 5,01 \quad 4,11 \quad 3,20$

Farinha peixe $\begin{array}{llllll}2,00 & 2,00 & 2,00 & 2,00 & 2,00 & 2,00\end{array}$

$\begin{array}{lllllll}\text { Protenose } & 0,95 & 1,15 & 1,35 & 1,55 & 1,75 & 1,95\end{array}$

$\begin{array}{lllllll}\text { Oleo br. soja } & 2,00 & 2,00 & 2,00 & 2,00 & 2,00 & 2,00\end{array}$

Farelo soja $\quad 20,72 \quad 18,65 \quad 16,58 \quad 14,51 \quad 12,43 \quad 10,36$

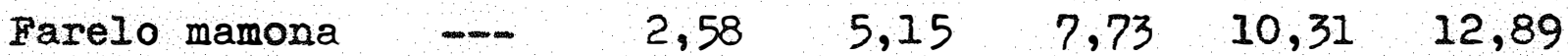

$\begin{array}{lllllll}\text { Calcáreo } & 1,00 & 1,00 & 1,00 & 1,00 & 1,00 & 1,00\end{array}$

$\begin{array}{lllllll}\text { Farinhe ossos } & 0,75 & 0,75 & 0,75 & 0,70 & 0,70 & 0,70\end{array}$

Sal iodizado $\begin{array}{lllllll}0,30 & 0,30 & 0,30 & 0,30 & 0,30 & 0,30\end{array}$

$\begin{array}{lllllll}\text { Premix } & 0,70 & 0,70 & 0,70 & 0,70 & 0,70 & 0,70\end{array}$ 
Tabela 11. Composição química bromatológica calculada das raçōes finais.

\begin{tabular}{|c|c|c|c|c|c|}
\hline$A$ & B & C & $D$ & $E$ & $F$ \\
\hline
\end{tabular}

Prot. bruta \% $18,81 \quad 18,81 \quad 18,81 \quad 18,81 \quad 18,82 \quad 18,82$ Ext. etéreo \% $\quad 5,74 \quad 5,72 \quad 5,72 \quad 5,70 \quad 5,68 \quad 5,66$ Mat. fibrosa $\% \quad 2,99 \quad 3,30 \quad 3,62 \quad 3,94 \quad 4,25 \quad 4,57$ Mat. mineral \% $4,66 \quad 4,68 \quad 4,69 \quad 4,67 \quad 4,69 \quad 4,72$ $\begin{array}{llllllll}\text { Cálcio (Ca) } \% & 0,87 & 0,88 & 0,89 & 0,88 & 0,89 & 0,90\end{array}$ $\begin{array}{llllllll}\text { Fósf.tat.(P) } & \% & 0,55 & 0,55 & 0,55 & 0,55 & 0,56 & 0,56\end{array}$ $\begin{array}{llllllll}\text { Fósf.disp.(P) } & \% & 0,32 & 0,32 & 0,32 & 0,31 & 0,32 & 0,32\end{array}$ Energ. metaboli $\begin{array}{llllllll}\text { zável } & \mathrm{Kcal} / \mathrm{kg} & 3.013 & 3.012 & 3.012 & 3.013 & 3.010 & 3.011\end{array}$ 
Tabela 12. Aminograma calculado das rações finais ( $\mathrm{g} / 100 \mathrm{~g}$ de amostra)

\begin{tabular}{|c|c|c|c|c|c|c|}
\hline \multirow{2}{*}{ Aminoácidos } & \multicolumn{6}{|c|}{ Tratamentos } \\
\hline & A & B & $\mathrm{C}$ & $D$ & $E$ & $\mathrm{~F}$ \\
\hline Arginina & 1,147 & 1,149 & 1,151 & 1,154 & 1,155 & 1,157 \\
\hline Cistina & 0,345 & 337 & 330 & 322 & 314 & 306 \\
\hline Fenilalanina & 898 & 888 & 877 & 866 & 856 & 845 \\
\hline Glicina & 847 & 840 & 834 & 827 & 819 & 812 \\
\hline Histidina & 472 & 463 & 455 & 447 & 439 & 432 \\
\hline Isoleucina & 757 & 753 & 751 & 748 & 746 & 741 \\
\hline Leucina & 1,653 & 1,655 & 1,656 & 1,658 & 1,660 & 1,661 \\
\hline Lisina & 973 & 973 & 973 & 973 & 973 & 973 \\
\hline Metionina & 392 & 392 & 392 & 392 & 392 & 396 \\
\hline Tirasina & 529 & 527 & 524 & 522 & 519 & 517 \\
\hline Treonina & 687 & 681 & 677 & 672 & 668 & 662 \\
\hline Priptofano & 212 & 206 & 201 & 196 & 190 & 185 \\
\hline Valina & 950 & 961 & 973 & 986 & 997 & 1,008 \\
\hline
\end{tabular}


4.7. Peso corporal, consumo de ração e conversão alimentar

As médias dos pesos corporais das aves foram obtidas semanalmente, a partir da 2 a semana de idade.

As pesagens foram efetuadas para cada sexo em separado, e depois de obtida a média do peso para cada sexo, se obtinha a média geral da parcela.

A conversão alimentar média para cada parcela foi calculada semanalmente, dividindo-se os resultados de con sumo alimentar acumulado, pelo peso total das aves vivas e mortas, naquela semana.

- controle de consumo de ração foi feito semanalmente, por ocasião da pesagem das aves. O consumo médio por parcela foi obtido multiplicando-se o resultado de peso médio das aves sobreviventes pela conversão alimentar correspondente.

\subsection{Mortalidade.}

- registro da mortalidade era feito no dia do evento. Assim que era encontrada, a ave morta era retirada - da divisão e o seu peso anotado.

As aves eram posteriormente necropsiadas, para a determinação da "causa mortis".

\subsection{Erro de sexagem}

Os erros de sexagem surgidos durante o trabaTho experimental eram corrigidos na ocasião das pesagens. Nes ta oporturidade, ao se constatar o erro, era 0 mesmo anotado e a ave, a partir daquele momento, passava a pertencer ao outro sexo.

Os erros de sexagem começaram a ser observados a partir do 212 dia de idade das aves e continuaram sendo no- 
tados até 0 560 dia de idade.

Os caracteres observados para a determinação do erro foram: desenvolvimento de crista e barbelas.

\subsection{Análise bio-econômica}

Tomando por base a composição das rações iniciais e finais, foi realizada análise bio-econômica para verí ficação dos efeltos ocasionados pela utilização do farelo de mamona destoxicado.

o custo por tonelada de ração, tanto na fase 1 nicial quanto na final, foi calculado para todas as raçōes. Para estes cálculos, só foram utilizados os custos referentes às matérias primas, nāo se levando em conta os demais custos de produção.

Os preços que foram considerados para as matérias primas das raçōes, foram os preços cotados pela Rações A nhanguera S.A., junto aos fornecedores, no mês de março do 1977.

Os preços por quilo de produto foram os seguin

tes:

e\$

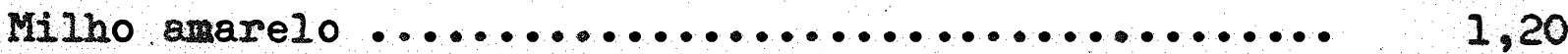

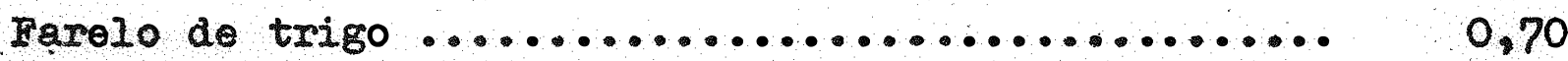

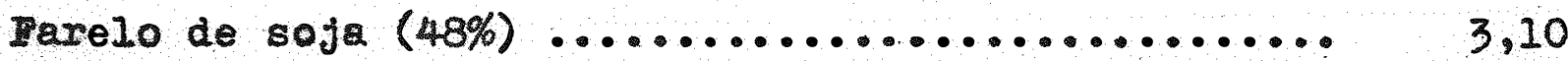

Farelo do mamona (Lex Proteico) .............. 2,20

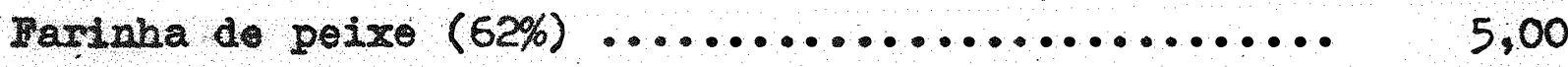

Protenose ............................... $\quad 4,10$

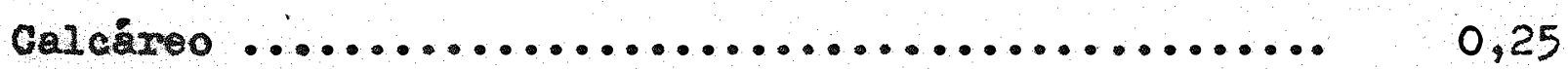

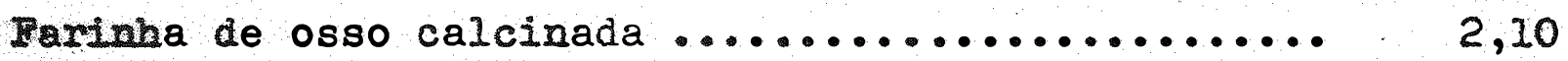

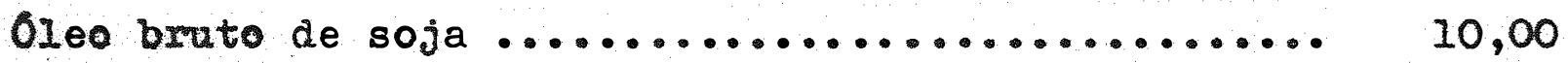


Sal iodizado ........................................ 0,85

Vitamina $\&(500.000 \mathrm{UI} / g) \ldots \ldots \ldots \ldots \ldots \ldots \ldots \ldots \ldots \ldots$

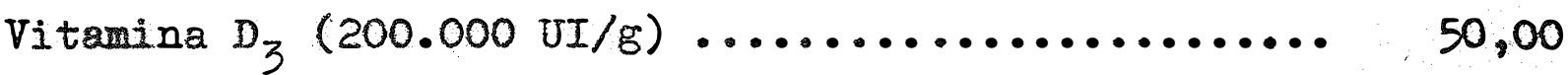

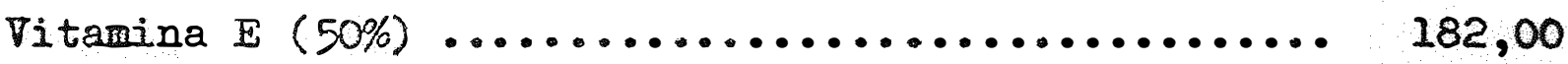

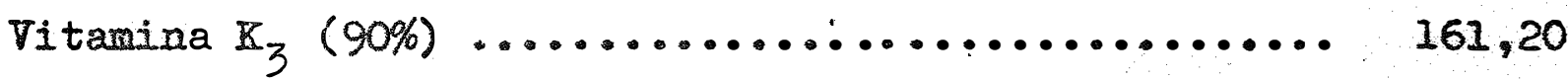

Vitamina $B_{1}(98 \%) \ldots \ldots \ldots \ldots \ldots \ldots \ldots \ldots \ldots . \ldots \ldots . \ldots \ldots, 20$

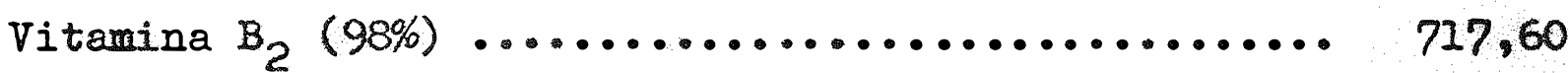

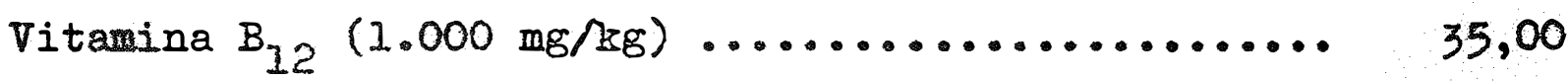

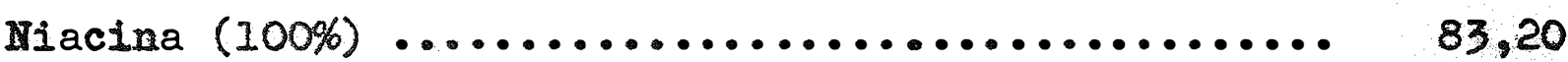

DI-Pantotenato de cálcio (80\%) ................ 120,00

Cloreto de colina (50\%) ......................... 10

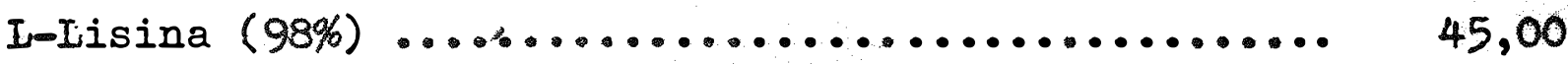

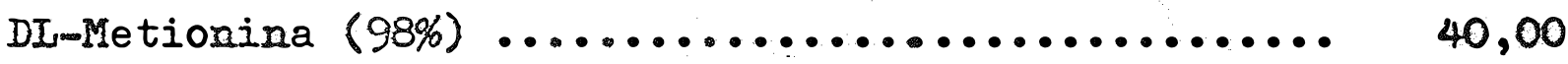

SaI mineral IRCA ......................... 9,00

* Cobar 100 (Monensina sódica - 100 ppm) ......... 41,53

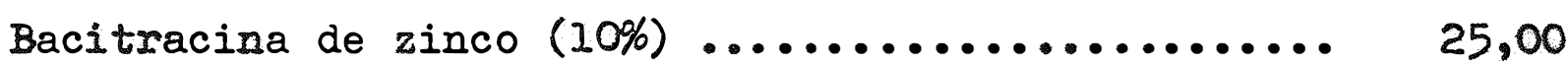

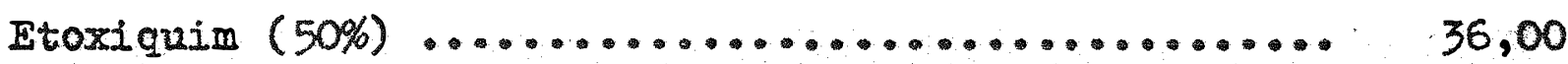

- Home comercial do produto fabricado pela ELANCo.

- preço por quilo de ave viva considerado foi de E\$7,95, de acordo coll a seção Mercados e Preços da AVICUITURA BRASIJEIRA (1977).

Baseados nos preços calculados das rações iniciais e finais e no consumo alimentar médio das aves, foram $\underline{\theta}$ fetuados os cálculos referentes à despesa. 
Considerando-se o preço do quilo de frango vivo e o peso médio das aves aos 35 e 56 dias de idade, foram e fetuados os cálculos referentes à receita.

Foi então calculado o lucro médio relativo, por tratamento e por ave, aos 35 . e 56 dias de idade das aves, subtraindo-se a despesa da receita. 
5. RESULTADOS

Foram analisados resultados de ganho de peso médio, consumo e conversão alimentares médios, aos 35 dias, entre o 360 e $\circ 569 \mathrm{dia}$, e aos 56 dias de idade.

Foi feita, ainda, a análise bio-econômica dos diferentes tratamentos.

5.1. Peso médio, consumo alimentar médio e conversão alimentar média das aves, aos 35 dias de idade

Os dados referentes ao peso médio, consumo aIimentar médio e conversão alimentar média, aos 35 dias de idade, são apresentados na Tabela 13. As análises de variância correspondentes são apresentadas nas Tabelas 14, $15 \bullet 16$. 
Tabela 13. Peso médio, consumo alimentar médio e conversão alimentar média das aves, aos 35 dias de idade.

\begin{tabular}{cccc}
\hline & $\begin{array}{c}\text { Peso } \\
\text { médio } \\
\text { Tratamentos }\end{array}$ & $\begin{array}{c}\text { Consumo } \\
\text { alimentar } \\
\text { médio }(\mathrm{kg})\end{array}$ & $\begin{array}{c}\text { Conversão } \\
\text { alimentar } \\
\text { média }\end{array}$ \\
\hline A & 0,978 & 1,854 & 1,897 \\
B & 1,008 & 1,926 & 1,912 \\
C & 1,008 & 1,961 & 1,945 \\
D & 1,021 & 1,969 & 1,928 \\
E & 1,006 & 1,989 & 1,978 \\
F & 0,974 & 2,002 & 2,054 \\
\hline
\end{tabular}


Tabela 14. Análise de variância do peso médio das aves, aos 35 dias de idade.

\begin{tabular}{|c|c|c|c|c|}
\hline Fonte de variação & G.I. & S.Q. & Q.M. & F \\
\hline Regressão linear & 1 & 0,000005 & 0,000005 & 0,01 \\
\hline Regressão quadrática & 1 & 0,006475 & 0,006475 & $17,59 * *$ \\
\hline Regressão cúbica & 1 & 0,000075 & 0,000075 & 0,20 \\
\hline Regressão 49 grau & 1 & 0,000144 & 0,000144 & 0,39 \\
\hline Regressão 50 grau & 1 & 0,000301 & 0,000301 & 0,82 \\
\hline (Pratamentos) & (5) & 0,007001 & 0,001400 & $3,80^{*}$ \\
\hline Blocos & 3 & 0,001158 & 0,000386 & 2,05 \\
\hline Residuo & 15 & 0,005515 & 0,000368 & \\
\hline Total & 23 & 0,013674 & & \\
\hline
\end{tabular}

- Significativo ao nível de $5 \%$ de probabilidade

** Significativo ao nivel de $1 \%$ de probabilidade C. . . $=3,74 \%$ 
Tabela 15. Análise de variância do consumo alimentar médio das aves, aos 35 dias de idade.

Fonte de variação

G.I.

S.Q.

Q.M.

F

Regressão linear

1

0,050464

0,050464

$34,33^{* *}$

Regressão quadrática I

0,006001

0,006001

4,08

Regressão cúbica

I

0,001602

0,001602

1,09

Regressão 40 grau

1 .

0,000151

0,000151

0,10

Regressão 50 grau

$1 \quad 0,000112$

0,000112

0,08

(Tratamentos)

Blocos

Resíduo

Total
(5)

0,058331

0,011666

$7,94^{* *}$

3

0,009174

0,003058

2,08

0,022050

0,001470

23

0,089555

* Significativo ao nivel de $1 \%$ de probabilidade C.V. $=5,54 \%$ 
Tabela 16. Análise de variância da conversão alimentar média das aves, aos 35 dias de idade.

Fonte de variação G.I. S.Q. G.M. G F

\begin{tabular}{lccccc}
\hline Regressão linear & 1 & 0,053572 & 0,053572 & $51,46^{* *}$ \\
Regressão quadrática & 1 & 0,006528 & 0,006528 & $6,27^{*}$ \\
Regressão cúbica & 1 & 0,003524 & 0,003524 & 3,38 \\
Regressão 40 grau & 1 & 0,000122 & 0,000122 & 0,12 \\
Regressão 50 grau & 1 & 0,001832 & 0,001832 & 1,76 \\
& & & & \\
\hline (Tratamentos) & (5) & 0,065578 & 0,013116 & $12,60^{* *}$ \\
Blocos & 3 & 0,005783 & 0,001928 & 1,85 \\
Residuo & 15 & 0,015617 & 0,001041 & \\
\hline & & & & & \\
\hline Total & 23 & 0,086978 & & & \\
\hline
\end{tabular}

* Significativo ao nivel de $5 \%$ de probabilidade

** Significativo ao nivel de $1 \%$ de probabilidade

C.V. $=5,87 \%$ 
Verifica-se que os tratamentos mostraran diferenças estatisticamente significativas, quanto ao peso médio $(P<0,05)$, consumo alimentar médio $(P<0,01)$ e conversão alimentar média $(P<0,01)$.

Pelo teste de Tukey foram comparadas, entre si, as médias dos tratamentos.

Para peso médio, $D>F$ ao nível de $5 \%$ de proba bilidade. As outras médias não diferira estatisticamente en tre si.

Para consumo alimentar médio, $A<C$ ao nivel de $5 \%$ de probabilidade e A $<$, E e F ao nível de $1 \%$ de proba bilidade.

Para conversão alimentar média, $A<E$ e $E<P$, ao nivel de $5 \%$ de probabilidade; $A<F, B<F, C<F$ e $<F$ ao nivel de $1 \%$ de probabilidade.

Quando os graus de liberdade de tratamentos fo ram subdivididos em seus componentes de regressão, pelo método dos polinômios ortogonais, observou-se que, quanto ao peso médio das aves aos 35 dias de idade, houve resposta quadrática aos níveis crescentes de adição do farelo de mamona destoxicado às rações $(P<0,01)$. Quanto ao consumo alimentar médio aos 35 dias de idade, houve resposta linear aos níveis crescentes de adição do farelo de mamona às raçōes $(\mathrm{P}<0,01)$. Com relação à conversão alimentar média aos 35 dias de idade, houve resposta quadrática aos níveis crescentes de adição do farelo de mamona às rações $(P<0,05)$.

A representação gráfica da regressāo do peso médio, consumo alimentar médio e conversāo alimentar média, a parece nas figuras 1,2 e 3 , respectivamente. 


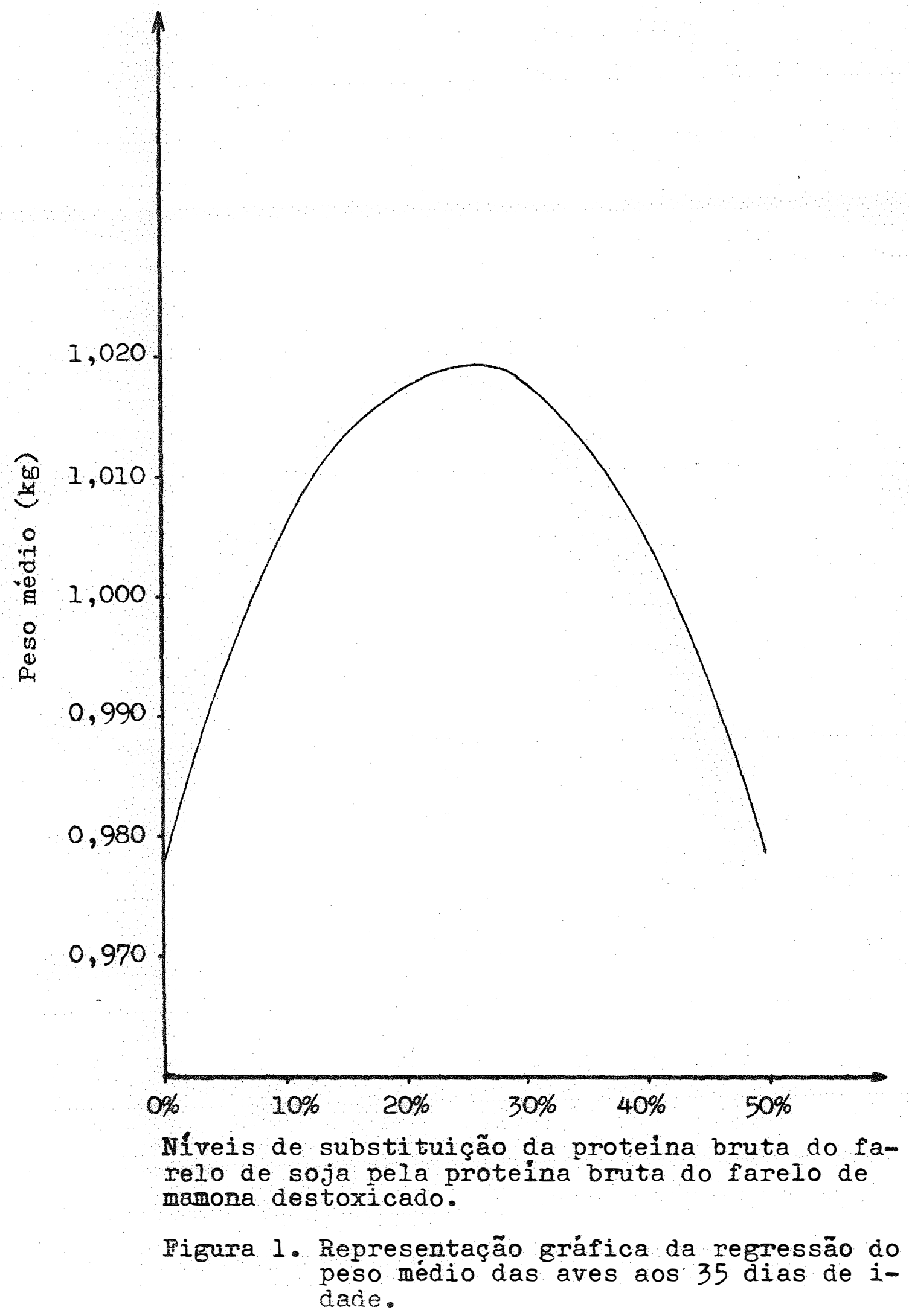




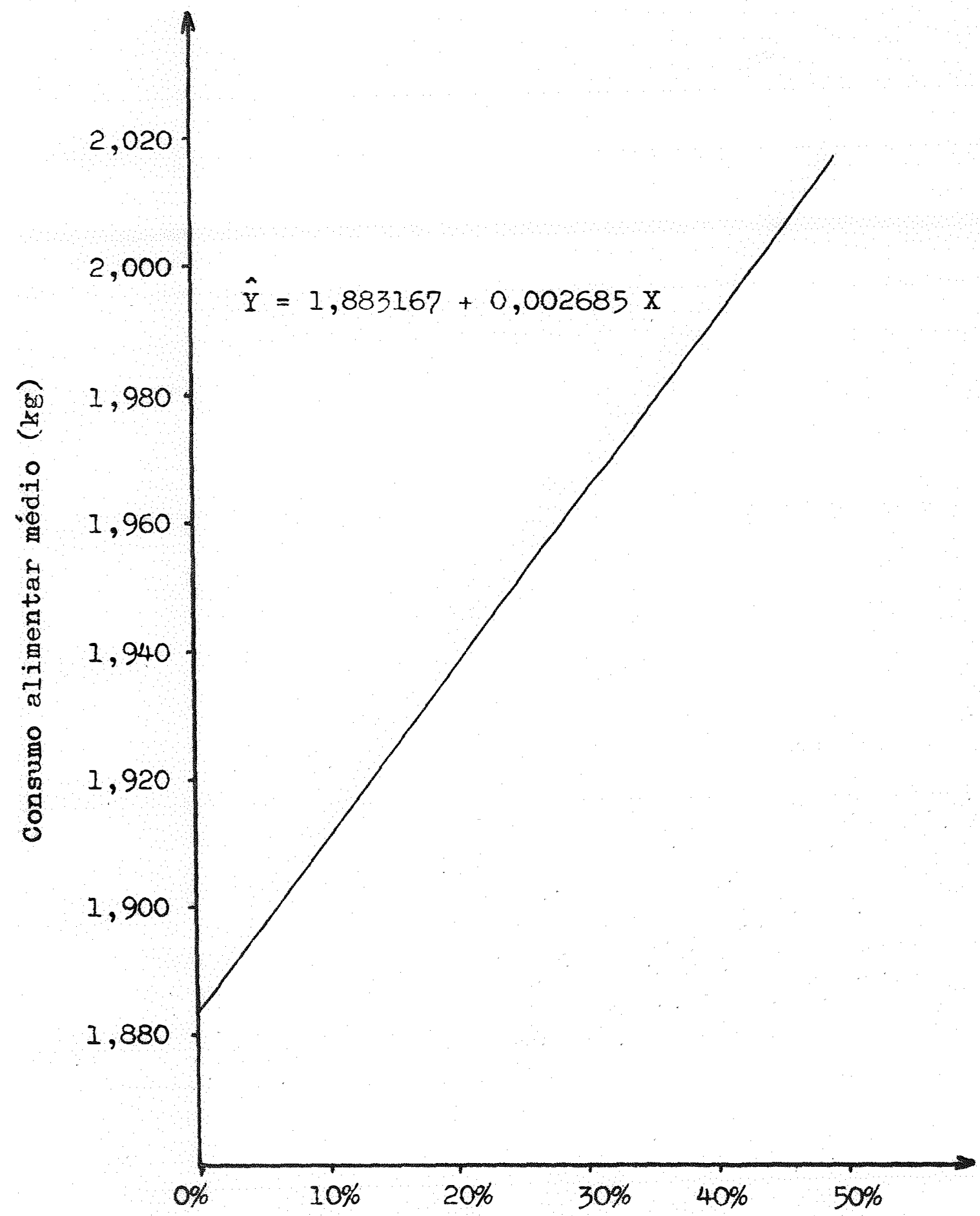

Níveis de substituição da proteina bmuta do farelo de soja pela proteína bruta do farelo de mamona destoxicado.

Figura 2. Representação gráfiça da regressão do consumo alimentar médio das aves, aos 35 dias de idade. 
51.

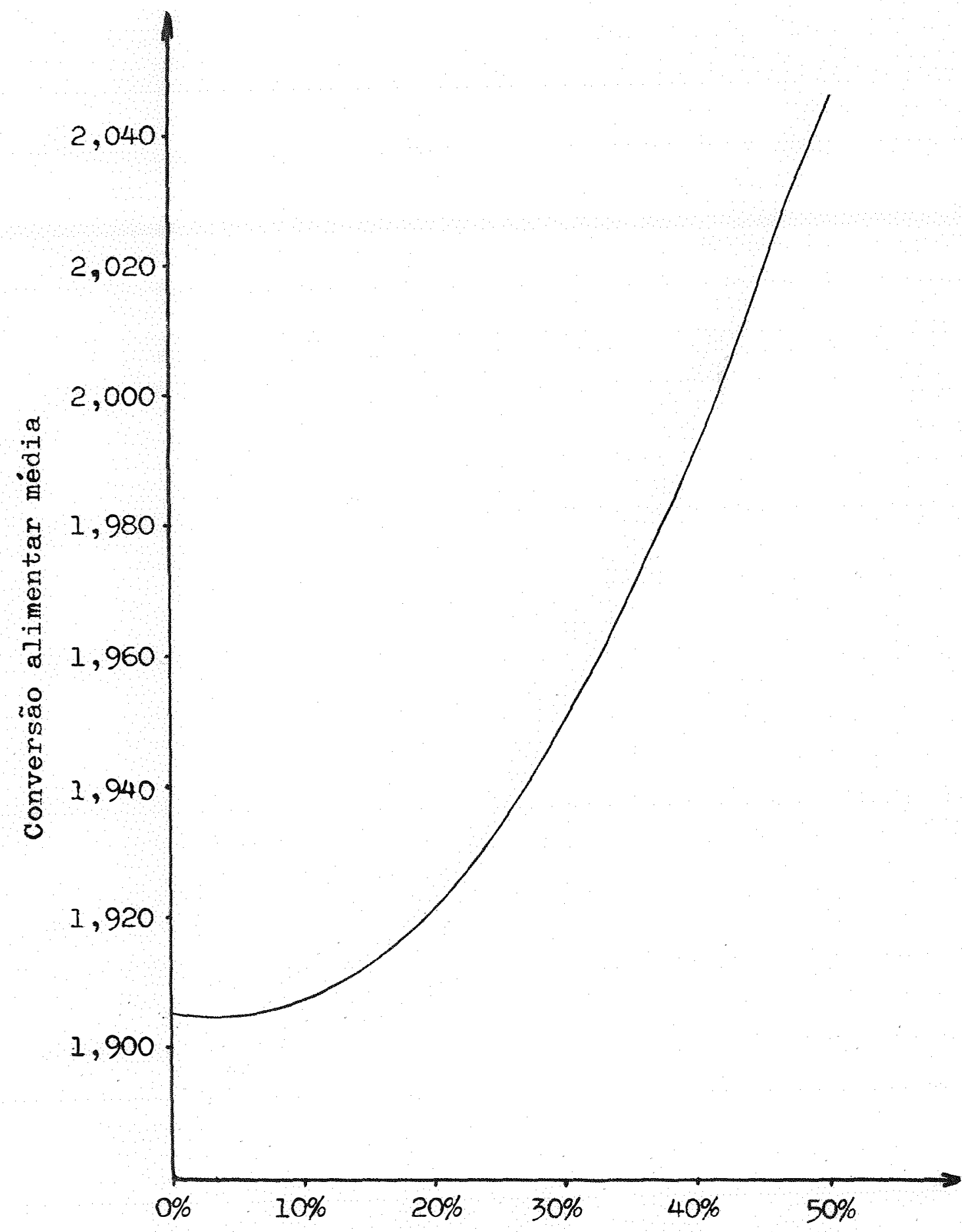

Niveis de substituição da proteína bruta do farelo de soja pela proteina bruta do farelo de mamona destoxicado.

Figura 3. Representação gráfica da regressão da conversâo alimentar média das aves aos 35 dias de idade. 
5.2. Ganho de peso médio, consumo alimentar médio e conver são alimentar média das aves, entre 36 e 56 dias de idade.

Os dados referentes ao ganho de peso médio, consumo alimentar médio e conversão alimentar média, entre 36 e 56 dias de idade das aves, são apresentados na Tabela 17. As análises de variância correspondentes são apresentadas nas Tabelas 18,19 e 20 .

Tabela 17. Ganho de peso médio, consumo alimentar médio e con versäo alimentar média das aves, entre 36 e 56 dias de idade.

\begin{tabular}{cccc}
\hline Tratamentos & $\begin{array}{c}\text { Ganho de } \\
\text { peso médio }\end{array}$ & $\begin{array}{c}\text { Consumo ali- } \\
\text { mentar médio }\end{array}$ & $\begin{array}{c}\text { Conversäo alí } \\
\text { mentar média }\end{array}$ \\
\hline A & $0,972 \mathrm{~kg}$ & $2,701 \mathrm{~kg}$ & 2,781 \\
B & $1,021 \mathrm{~kg}$ & $2,870 \mathrm{~kg}$ & 2,811 \\
C & $0,961 \mathrm{~kg}$ & $2,775 \mathrm{~kg}$ & 2,890 \\
D & $0,994 \mathrm{~kg}$ & $2,831 \mathrm{~kg}$ & 2,847 \\
E & $0,977 \mathrm{~kg}$ & $2,844 \mathrm{~kg}$ & 2,912 \\
F & $1,016 \mathrm{~kg}$ & $2,949 \mathrm{~kg}$ & 2,901 \\
\hline
\end{tabular}


Tabela 18. Análisê de variância do ganho de peso médio das aves, entre 36 e 56 dias de idade.

Fonte de variação

G.I.

S.Q.

Q.M.

Regressão linear

1

0,000907

0,000907

1,59

Regressāo quadrática I

0,000691

0,000691

1,21

Regressão cúbica

1

0,003485

0,003485

$6,10^{*}$

Regressāo 40 grau

1

0,001344

$0,001344 \quad 2,35$

Regressão 50 grau

1

0,005686

0,005686

$9,96 *$

(Tratamentos)

(5)

0,012113

0,002423

4,24*

Blocos

3

0,002398

0,000799

1,40

Residuo

15

0,008561

0,000571

romix

23

0,023072

- Significativo ao nivel de $5 \%$ de probabilidade

* - Significativo ao nivel de $1 \%$ de probabilidade

C. $\nabla .=4,97 \%$ 
Tabela 19. Análise de variância do consumo alimentar médio das aves, entre 36 e 56 dias de idade.

Fonte de rariação G.I. S.Q. S.M. $\quad$ Q. F

$\begin{array}{lllll}\text { Regressāo linear } & \text { I } & 0,084877 & 0,084877 & 21,14^{* *} \\ \text { Regressão quadrätica } & 1 & 0,000523 & 0,000523 & 0,13 \\ \text { Regressão cúbica } & 1 & 0,031800 & 0,031800 & 7,92^{*} \\ \text { Regressão 42 grau } & 1 & 0,011260 & 0,011260 & 2,80 \\ \text { Regressão 50 grau } & \text { I } & 0,013929 & 0,013929 & 3,47\end{array}$

(Tratamentos)

(5)

0,142389

0,028478

7,08**

Blocos

3

0,031281

0,010427

2,60

Resíduo

15

0,060226

0,004015

TOMAL

23

0,233896

* - Significativo ao nivel de $5 \%$ de probabilidade * - Significativo ao nivel de $1 \%$ de probabilidade C. $\nabla .=5,97 \%$ 
Tabela 20. Análise de variância da conversão alimentar média das aves, entre 36 e 56 dias de idade.

Fonte de variação

G.I.

S.Q.

Q.M.

F

Regressão linear

1

0,042140

0,042140

$5,45^{*}$

Regressāo quadrática 1

10,003158

0,003158

0,41

Regressão củbica

1

0,000101

0,000101

0,01

Regressão 49 grau

1

0,000024

0,000024

0,003

Regressão 52 grau

1

0,010414

0,010414

1,35

$\begin{array}{lcccc}\text { (Pratamentos) } & (5) & 0,055837 & 0,011167 & 1,44 \\ \text { Blocos } & 3 & 0,023651 & 0,007884 & 1,02 \\ \text { Besidue } & 15 & 0,115915 & 0,007728 & \end{array}$

TOMAT

23

0,195403

* - Bignificativo ao nlvel de $5 \%$ de probabilidade C. $\nabla .=3,70 \%$ 
Verifica-se que os tratamentos mostraram diferenças estatisticamente significativas, quanto ao ganho de pe so médio $(P<0,05)$ e consumo alimentar médio $(P<0,01)$.

Pelo teste de Tukey foram comparadas, entre si, as médias dos tratamentos.

Para ganho de peso médio, B > C e F>C ao nivel de $5 \%$ de probabilidade.

Para consumo alimentar médio, $B>A$ e $F>C$ ao nivel de $5 \%$ de probabilidade. F> A ao nível de $1 \%$ de probabilidade.

Com relação à conversão alimentar média, os tratamentos não mostraram diferenças estatisticamente signifí cativas entre si.

Quando os graus de liberdade de tratamento forom subdivididos em seus componentes de regressão, pelo método dos polinómios ortogonais, observou-se que, quanto ao ganho de peso médio das aves entre 36 e 56 dias de idade, houre uma resposta de 50 grau aos niveis crescentes de adição do IQ relo de mamona às raçōes $(P<0,01)$. Quanto ao consumo alimentar médio entre 36 e 56 dias de idade, houve uma resposta cúbica aos níveis crescentes de adição do fárelo de mamona às raçōes $(P<0,05)$. Com relação à conversão alimentar média entre 36 e 56 dias de idade, houve uma resposta linear aos ni vels crescentes de adição do farelo de mamona às raçōes $(P<0,05)$.

A representação gräfica da regressão do consumo alimentar médio e conversão alimentar mẻdia, aparece nas Figuras 4 e 5 , respectivamente. 


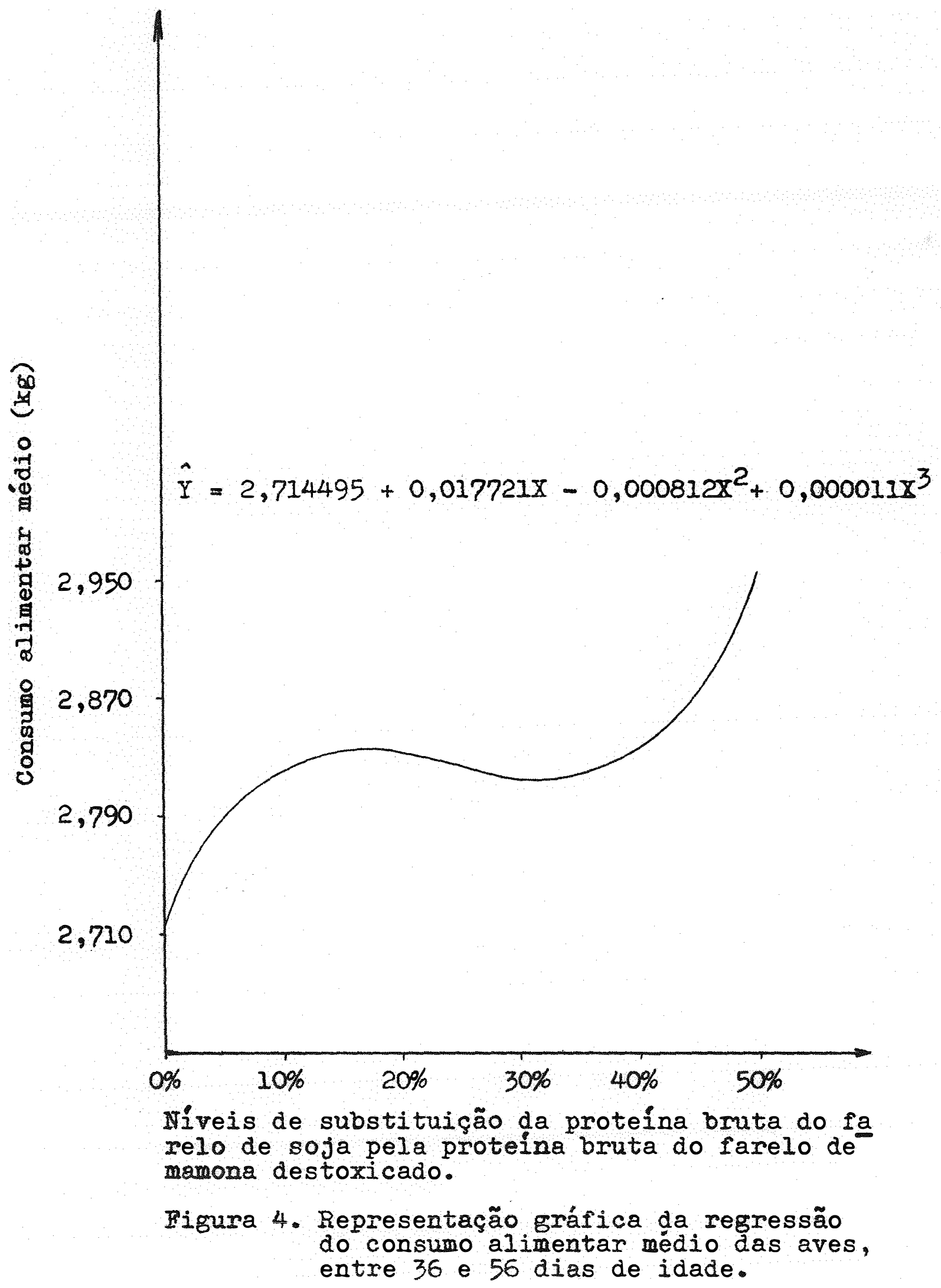




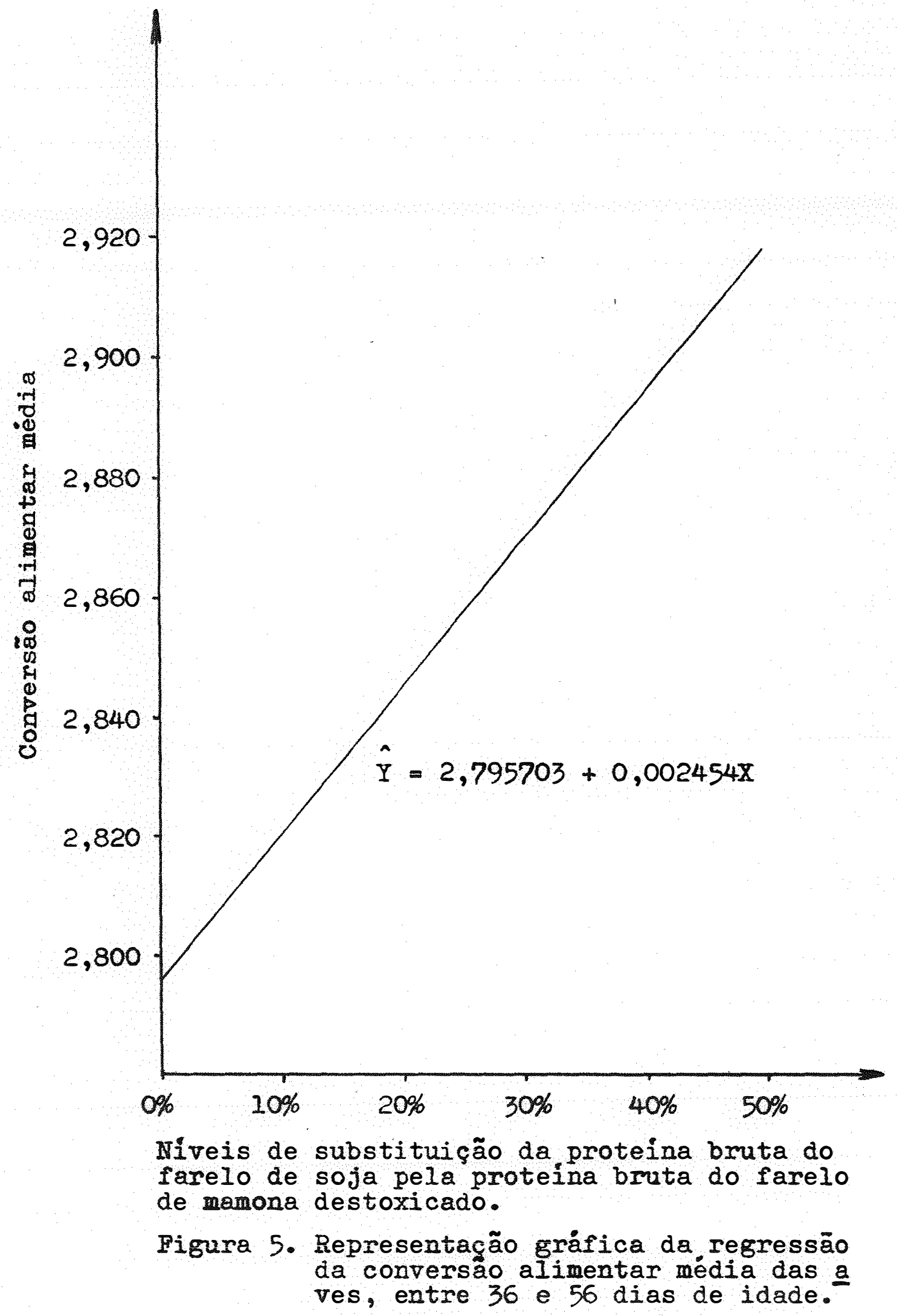


5.3. Peso médio, consumo alimentar médio e conversão alimentar média das aves, aos 56 dias de idade.

Os dados referentes ao peso médio, consuno ali mentar médio e conversão alimentar média das aves, aos 56 dias de idade, sāo apresentados na Tabela 21. As análises de variância correspondentes säo apresentadas nas Tabelas 22,23 e 24 .

Tabela 21. Peso médio, consumo alimentar médio e conversão alimentar média das aves aos 56 dias de idade.

\begin{tabular}{|c|c|c|c|}
\hline Tratamentos & $\begin{array}{l}\text { Peso } \\
\text { médio } \\
(\mathrm{kg})\end{array}$ & $\begin{array}{l}\text { Consumo } \\
\text { alimentar } \\
\text { médio ( } \mathrm{kg} \text { ) }\end{array}$ & $\begin{array}{c}\text { Conversăo } \\
\text { alinentar } \\
\text { nédía }\end{array}$ \\
\hline A & 1,949 & 4,554 & 2,337 \\
\hline B & 2,029 & 4,797 & 2,364 \\
\hline C & 1,969 & 4,736 & 2,406 \\
\hline D & 2,015 & 4,800 & 2,381 \\
\hline $\mathbf{E}$ & 1,983 & 4,834 & 2,437 \\
\hline $\mathbf{P}$ & 1,991 & 4,951 & 2,487 \\
\hline Média geral & 1,989 & 4,779 & 2,402 \\
\hline
\end{tabular}


Tabela 22. Análise de variância do peso médio das aves, aos 56 dias de idade.

Fonte de variação

G.I.

S.Q.

Q.M.

$P$

Regressāo linear

1

0,000775

0,000775

0,73

Regressão quadrática 1

0,002935

0,002935

2,76

Regressão cúbica

1

0,002535

0,002535

2,38

Regressão 49 grau

1

0,002368

0,002368

2,22

Regressāo 58 grau

1

0,008604

0,008604

$8,09 *$

(Tratamentos)

(5)

0,017217

0,003443

$3,24 *$

Blocos

3

0,004429

0,001476

1,39

Residuo

15

0,015968

0,001064

Total

23

0,037614

C.V. $2,95 \%$

- Significatiro ao nivel de $5 \%$ de probabilidade 
Tabela 23. Análise de variância do consumo alimentar médio das aves, aos 56 dias de idade.

Fonte de variação

G.I.

S.Q.

Q.1.

7

Regressão linear

1

0,266235

0,266235

$42,44 * *$

Regressão quadrática I

0,002982

0,002982

0,47

Regressão cúbica

1

0,007678

0,007678

$7,60^{*}$

Regressão 40 grau

1

0,014018

0,014018

2,23

Regressão 59 grau

1

0,011542

0,011542

1,84

(Pratamentos)

(5)

0,342455

0,068491

$10,92 * *$

Blocos

3

0,038614

0,012871

2,05

Resíduo

15

0,094092

0,006273

Total

23

0,475161

c. $=5,48 \%$

- Signiflcatiro ao nivel de $5 \%$ de probabilidade

** Significatiro ao nivel de $1 \%$ de probabilidade 
Tabela 24. Análise de variância da conversão alimentar média das aves, aos 56 dias de idade.

Fonte de variação

G.I.

S.Q.

Q.M.

F

\begin{tabular}{lcrrr} 
Regressão linear & 1 & 0,051057 & 0,051057 & $28,70^{* *}$ \\
Regressão quadrática & 1 & 0,001388 & 0,001388 & 0,78 \\
Regressão cúbica & 1 & 0,002497 & 0,002497 & 1,40 \\
Regressão 40 grau & 1 & 0,000005 & 0,000005 & 0,003 \\
Regressão 50 grau & 1 & 0,003377 & 0,003377 & 1,90 \\
& & & & \\
\hline & & & & \\
(Tratamentos) & $(5)$ & 0,058325 & 0,012665 & $6,56^{* *}$ \\
Blocos & 3 & 0,007785 & 0,002595 & 1,46 \\
Resíduo & 15 & 0,026679 & 0,001779 & \\
& & & &
\end{tabular}

Total

23

0,092789

C.V. $=4,50 \%$

* Significativo ao nivel de $1 \%$ de probabilidade 
Verifica-se que os tratamentos mostraram diferenças estatisticamente significativas, quanto ao peso médio $(P<0,05)$, consumo alimentar médio $(P<0,01)$ e conversão alimentar média $(\mathrm{P}<0,01)$.

Pelo teste de Tukey foran determinados os contrastes entre as médias dos tratamentos.

Para peso médio, $\mathrm{B}>\mathrm{A}$ ao nível de $5 \%$ de probe bilidade.

Para consumo alimentar médio, $\mathrm{F}>\mathrm{C}$ ao nivel de $5 \%$ de probabilidade e A $<$ B, D, E e F ao nível de $1 \%$ de probabilidade.

Para conversäo alimentar média, $E>A$ e $F>D$ ao nivel de $5 \%$ de probabilidade. $F>A$ e $B$ ao nivel de $1 \%$ de probabilidade.

Quando os graus de liberdade de tratamentos fo ram subdivididos em seus componentes de regressão, pelo método dos polinômios ortogonais, observou-se que, quanto ao peso médio houve uma resposta do 50 grau aos níveis crescentes de adição do farelo de mzmona às rações $(P<0,05)$. quanto ao consumo alimentar médio aos 56 dias de idade, houve uma resposta cúbica aos niveis crescentes de adição do farelo de mamona às rações $(P<0,005)$.

Com relação à conversão alimentar média aos 56 dias de idade, houve una resposta linear aos níveis crescentes de adição do farelo de mamona às rações $(P<0,01)$.

A representação gráfica da regressão do consumo alimentar médio e conversão alimentar média, aparece nas Figuras 6 e 7 , respectivamente. 


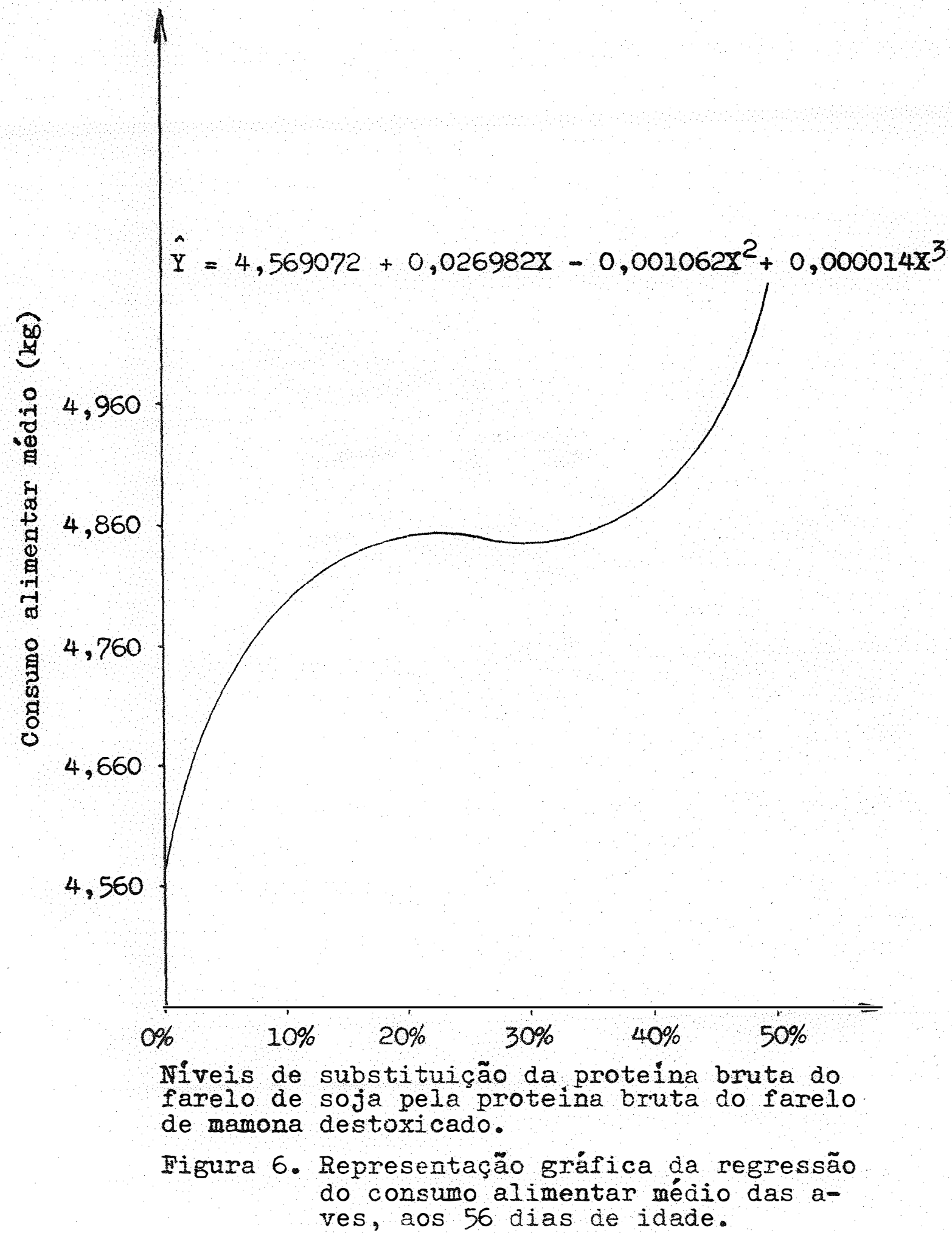




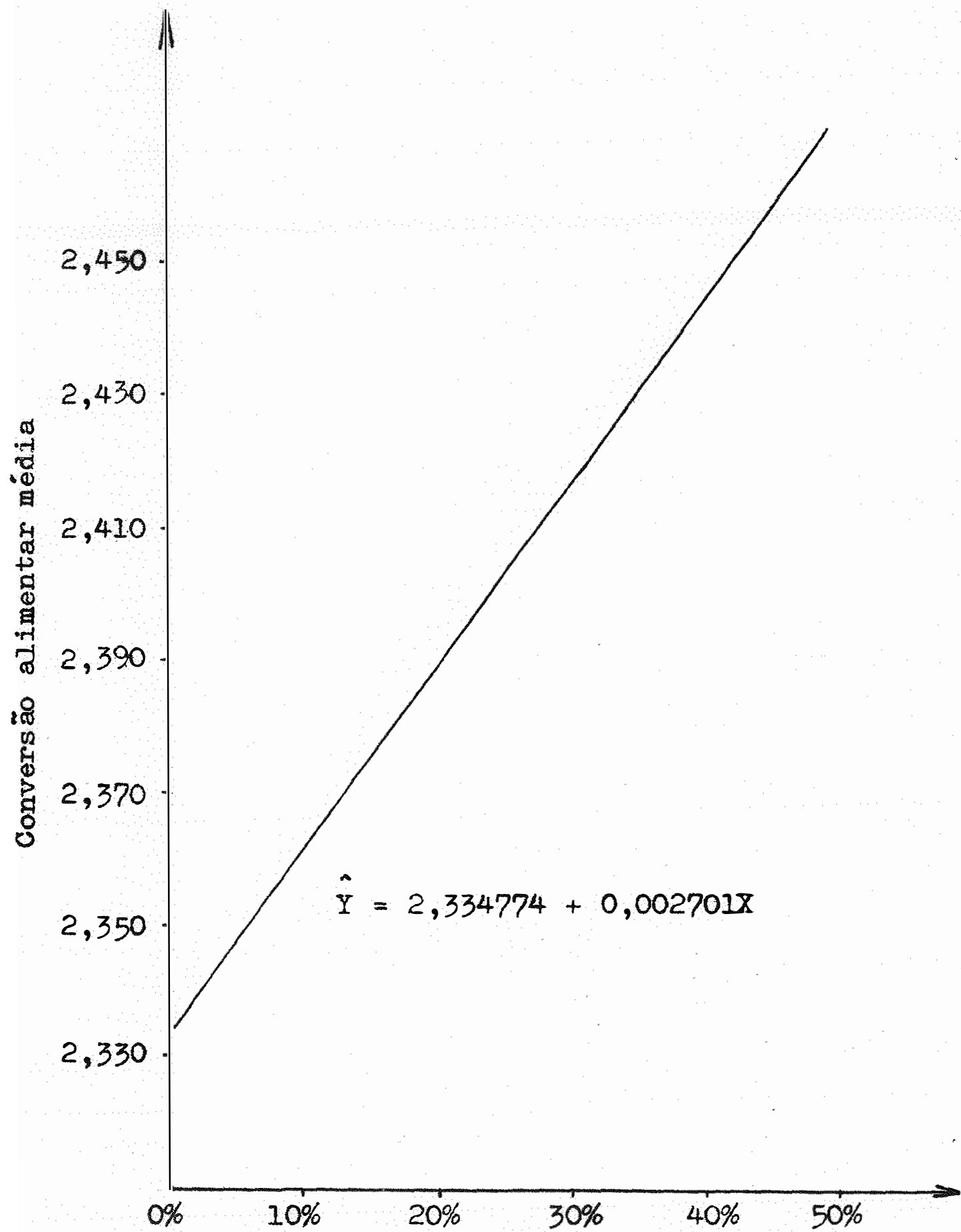

Niveis de substituição da proteina bruta do farelo de soja pela proteina bruta do farelo de mamona destoxicado.

Figura 7. Representacão gráfica da regressão da conversão alimentar média das a ves, aos 56 dias de iaade. 


\subsection{Mortalidade}

A partir do 30 dia de vida, quando foi feita a homogeneização das aves nos diferentes tratamentos e até o fi nal do experimento ( 56 dias de idade), morreram 24 aves, assim distribuídas: sete no tratamento $\mathrm{A}$, cinco no tratamento $B$, duas no tratamento $C$, duas no tratamento $D$, cinco no trate mento $\mathrm{E}$ e três no tratamento $\mathrm{F}$. A porcentagem média de morta lidade do 39 ao 560 dia do experimento foi, portanto, de 2,78 por cento. Os dados de necrópsia não foram conclusivos para se chegar a qualquer diagnóstico da "causa mortis" das aves.

\subsection{Erro de sexagem}

Das 864 aves, que a partir do 39 dia de idade participaram do experimento, 41 sofreram erros de sexagem, ou seja, 4,75\% de erro ao final do experimento. Dessas 41 aves, uma fêmea foi sexada como macho e 40 machos foran sexados como fêmeas. O erro de sexagem foi assin distribuido: on ze no tratamento A, cinco no tratamento B, seis no tratamento C, oi to no tratamento $D$, três no tratamento $E$ e oito no trata mento $\mathrm{F}$.

parcelas.

A Tabela 25 apresenta os erros de sexagem por 
Tabela 25. Erro de sexagem verificado durante o experimento $(*)$

\begin{tabular}{|c|c|c|c|c|c|c|c|c|c|c|c|c|}
\hline \multirow{3}{*}{ Blocos } & \multicolumn{12}{|c|}{ Tratamentos } \\
\hline & \multicolumn{2}{|c|}{ A } & \multicolumn{2}{|c|}{ B } & \multicolumn{2}{|c|}{ C } & \multicolumn{2}{|c|}{ D } & \multicolumn{2}{|c|}{$E$} & \multicolumn{2}{|c|}{$F$} \\
\hline & $M$ & $\mathbf{F}$ & M & $F$ & $\mathrm{M}$ & F & $M$ & $F$ & M & $F$ & $M$ & $\pi$ \\
\hline$I$ & 22 & 14 & 21 & 15 & 18 & 18 & 22 & 14 & 19 & 17 & 17 & 19 \\
\hline II & 21 & 15 & 19 & 17 & 21 & 15 & 18 & 18 & 18 & 18 & 22 & 14 \\
\hline III & 20 & 16 & 18 & 18 & 20 & 16 & 20 & 16 & 18 & 18 & 19 & 17 \\
\hline IV & 20 & 16 & 19 & 17 & 19 & 17 & 20 & 16 & 20 & 16 & 20 & 16 \\
\hline TOTAL & 83 & 61 & 77 & $6 ?$ & 78 & 66 & 80 & 64 & 75 & 69 & 78 & 66 \\
\hline
\end{tabular}

$M=$ machos

$F$ = fêmeas

(*) A mortalidade não está incluida

5.6. Análise bio-éconômica

Os dados de lucro relativo médio por ave e por tratamento, aos 35 e 56 dias de idade, são apresentados na Ta bela 26. 
Tabela 26. Iucro médio relativo, por tratamento e por ave, aos 35 e 56 dias de idade.

Mratamentos

Irucro médio, em cruzeiros

0 a 35 dias

0 a 56 dias
4
3,703
6,063
B
3,728
6,202
C
3,594
5,639
D
3,622
5,781
$E$
3,390
5,349
F
3,042
5,050

\subsection{Controle de coccidiose e verminose.}

Exames de fezes realizados semanalmente a partir do 210 dia de idade das aves, mostraram resultados negati vos para contagem de oocistos de Eimérias e ovos de vermes.

\subsection{Efeito laxativo do öleo de mamona}

Foi observada umidade anormalmente alta nas fe zes das aves, nos tratamentos que receberam níveis mais altos do farelo de mamona destoxicado. A umidade nas fezes pareceu aumentar à medida que o nivel do farelo de mamona nas raçōes se elevou. 
6. DISCUSSÃO

6.1. Desempenho

Foi observado que houve diferenças significati vas no desempenho das aves, avaliado pelo ganho de peso, consumo de raçāo e conversāo alimentar. Esses dados foram anali sados levando em consideração três períodos: até o 350 dia de idade das aves, do 360 ao 560 dia, e durante todo o período experimental, ou seja, os 56 dias.

Por ocasião dos desdobramentos dos tratamentos durante os estados de análise de regressão dos resultados, houve significância estatística para alguns dos componentes da regressāo. Isso mostrou que algumas tendências foram observadas quando níveis crescentes de farelo de mamona destoxi cado foram adicionados às rações.

6.1.1. Peso médio, consumo alimentar médio e conversão alimentar média das aves, aos 35 dias de $\dot{i}$ dade

Na primeira fase de criação ( 0 a 35 dias de idade), quando o valor nutritivo do farelo de mamona foi ava- 
liado na ração inicial, verificou-se que quanto ao peso médio das aves, houve resposta quadrática $(P<0,01)$ aos níveis crescentes de adição do farelo de mamona às raçōes. Observan do a representação gráfica dessa regressão (Figura 1), podese verificar que o crescimento máximo das aves ocorreu ao redor do nível de $30 \%$ de substituição da proteina do farelo de soja pela proteína do farelo de mamona destoxicado. Nesse ní vel, o farelo de mamona contribuiu com $11,60 \%$ do peso total da ração.

Estes resultados estão de acordo com os obtidos por COSTA e IAUN (1961) que substituiram uma mistara composta de $40 \%$ de farelo de soja, $40 \%$ de farelo de amendoim e $20 \%$ de farelo de trigo, por farelo de mamona destoxicado. Es ses autores utilizaram o farelo de mamona ate o nivel de $20 \%$ da ração e observaram que até o nível de $10 \%$, o ganho de peso médio aumentou. A partir desse nível, o ganho de peso médio diminuiu. Estão também de acordo com os resultados encontrados por KODRAS et alii (1949), que alimentaram pintos de zero a três semanas de idade com raçōes que continham $0,8,7,17,4$ e $34,8 \%$ de farelo de mamona destoxicado. A ração que continha $8,7 \%$ de farelo de mamona proporcionou maior ganho de peso às aves, quando comparada com as demais.

Ainda nesta fase de criação, no tocante ao con sumo alimentar, houve uma resposta linear $(P<0,01)$ aos niveis de adiçāo do farelo de mamona às rações. A representação gráfica dessa regressão (Figura 2) mostra que à medida que o nível do farelo de mamona aumentou nas raçőes, o consumo alimentar tambén aumentou de maneira linear.

Estes resultados estão de acordo com os obtidos por CARVALHO et alii (1976) que utilizaram farelo de mamo na destoxicado, em rações para poedeiras, até o nivel de $10 \%$. Estão em desacordo com os resultados obtidos por COSTA e LAON (1961) já citados anteriormente e GADELHA et alii (1973), que 
substituiram $0,4,8$ e $12 \%$ do farelo de soja por iguais niveis de farelo de mamona destoxicado em rações de frangos, 0 qual reduziu o consumo alimentar.

Quanto à conversão alimentar mẻdia, houve resposta quadrática $(P<0,05)$ à adição de niveis crescentes de farelo de mamona às raçōes. A Figura 3 mostra que à medida que o nível de adição do farelo de mamona se elevou nas raf̧ões, a conversäo alimentar piorou.

Os resultados estão de acordo com os obtidos por GADELHA et alii (1973), já citados anteriormente, que observaran que à medida que o nírel do farelo de mamona se elevou nas raçōes, a conversão alimentar piorou. Estão en desacordo com os resultados obtidos por cOSTA e IAAUN (1961), também já citados anteriormente, que constataram que à medida que o farelo de mamona destoxicado aumentou nas rações, a con versão alimentar melhorou até 0 nível de adição de $10 \%$ do farelo de mamona, piorando a partir desse ponto.

Os resultados de ganho de peso, crescentes até - nivel de $30 \%$ de substituição da proteína do farelo de soja pela proteína do farelo de mamona destoxicado, devem ter sido devidos ao aumento do consumo alimentar.

Estes resultados sugerem que as raçōes que con tinham maiores quantidades de farelo de mamona apresentaram niveis energéticos ligeiramente menores. Por isto, aos 35 dias de idade das aves, esta menor concentração energética das raçōes foi responsável pelo aumento linear do consumo.

A causa provável do menor nivel energético nas fórmulas que continham níveis mais elevados do farelo de mamo na, foi o não conhecimento do teor exato da energia metabolizável contida no farelo de mamona. o valor da energia metabo lizável ( $1.650 \mathrm{Hcal} / \mathrm{kg}$ ) do farelo de mamona foi obtido através de informação pessoal dada pelo Dr. JOst EDUARDO BUTOIO, Diretor Técnico da Rações Anhanguera S.A., que realizou vá- 
rios trabalhos, não publicados, com o farelo de mamona destoxicado na alimentação de aves.

Como aquele valor foi talvez considerado acima do valor real, as raçōes formuladas com maiores niveis de farelo de mamona, apresentaram, provavelmente, náveis energét1cos mais baixos.

Além do nivel de $30 \%$ de substituição da proteí na do farelo de soja pela proteína do farelo de mamona, o peso médio diminuiu. Apesar desses resultados, só houve diferença significativa entre os tratamentos D e F. 0 A. atribuiu a dininuição do peso médio ao efeito laxativo do óleo re sidual presente no farelo. Esse efeito pode ocasionar o desbalanceamento das rações pelo desperdicio de nutrientes elimi nados, parcialmente digeridos.

6.1.2. Ganho de peso médio, consumo e conversão alimentar médios das aves, entre 36 e 56 e entre 0 e 56 dias de idade.

Os resultados obtidos de ganho de peso médio das aves entre 36 e 56 dias, e de peso médio entre 0 e 56 dias, nāo permitiram tirar conclusōes definidas. Os níveis selupre crescentes do farelo de mamona nas rações deram resultados de ganho de peso bastante irregulares e consequentemente inconclusivos.

Ao nivel de substituição de $10 \%$ da protelna do farelo de soja pela do farelo de mamona, o ganho de peso médio foi o mais elevado observado, diferindo significativamente do tratamento $c$, entre 36 e 56 dias de idade e do tratamen to A, entre 0 e 56 dias de idade. Esse nivel de substituição após os 35 dias de idade, sempre proporcionou maior ganbo de peso médio às aves, apesar dos resultados irregulares obtidos nos outros níveis de substituição. 
O efeito laxativo do oleo de mamona, que pareceu ser mais acentuado na fase final do experimento, conforme os nfveis do farelo de mamona foram se elevando nas raçōes, deve ter interferido na absorção dos nutrientes pelas as, fazendo com que fossem obtidos resultados tão irregulares.

Quanto ao consumo alimentar, houve resposta o bioa $(P<0,05)$ aos niveis de adição do farelo de mamona às ragões.

As representações gráficas das regressōes (Figuras 4 e 6) mostram que houve uma tendência no sentido de ú mentar o consumo à medida que o nivel de farelo de mamona se lovou nas rações. Estes resultados estão de acordo com os obtidos por CARVALHO et alii (1976) e estão em desacondo com os resultados obtidos por COSTA e IAUH (1961) e GADELHA et alii, (1973), todos já citados anteriórmente.

Quanto à conversão alimentar média, houve resposta linear aos níveis de adição do farelo de mamona às raçōes. Os tratamentos não diferiram estatisticamente entre si no periodo de 36 a 56 dias. No período de 0 a 56 dias, o tra tamento $\mathrm{E}$ foi significativamente maior que a testemunha e 0 tratamento $F$ foi significativamente maior que os tratamentos A, B e D.

As representações gráficas das regressões (Figuras 5 e 7) mostram que à medida que os níveis do farelo de ma se elevaram nas rações, as conversões alfimentares pioraran.

Estes resultados estão de acordo com os obtidos por GADELEA et alii (1973) que observaram que à medida que o teor do farelo de mamona se elevou nas raçōes, a conve: são alimentar piorou. Estão em desacordo com os resultados obtldos por COSPA e LAUN (1961), que observaram que à medida que - farelo de mamona aumentou nas rações, a conversão alimentar melborou até o nível de adição de 10\% do farelo, piorando a partir desse ponto. 


\subsection{Estudo econômico da utilização do farelo de mamona destoxicado em rações de frangos de corte.}

Pela análise bio-econômica foi observado, de u ma maneira geral, que à medida que o nivel do farelo de mamona se elevou nas rações, o lucro médio relativo por ave diminuiu. Isto se prende ao fato de que o farelo de mamona, na casião do experimento, estava ao preço de $₫ \$ 2,20$ por quilo. Destes, $\$ 0,70$ se refere ao frete de Recife a São Paulo, 0 que elevou consideravelmente 0 preço final das rações.

Sendo o farelo de mamona destoxicado produzido apenas no nordeste, nos Estados de Pernambuco e Bahia, sua utilização em outras regiões pode se tornar anti-econômica.

Caso passe a ser produzido em outras regiões, onde deverá ter seu preço atual reduzido ou se trate de utili zá-lo em rações nas regiöes do nordeste onde é atualmente pró duzido, certamente proporcionará vantagens econômicas quando utilizado em rações iniciais para frangos de corte, até o nivel de $11,60 \%$ das mesmas. Em rações finais, as conclusões não podem ser as mesmas, em virtude dos resultados irregulares obtidos no presente trabalho, no periodo de 36 a 56 diab de idade das aves.

Se for considerado apenas o preço das raçōes, tanto iniclais quanto finais, se verificará que à medida que - nivel de substituição do farelo de soja pelo farelo de memo na se Gievou nas rações, o preço da ração tambẻ se elevou. Isto foi devido aos seguintes fatores: (a) - 0 farelo de saja foi substituido por quantidades proporcionalmente maiores de farelo de mamona; (b) - Em virtude da deficiência dos aminoácidos lisina e metionina, do farelo de mamona, houve necessidade da suplementação dos mesmos através do premix. Esta suplementaçāo aumenton à medida que foi elevado o nivel do fare Io de mamona nas rações. 
- Iucro médio relativo por ave foi maior ao ni vel de $10 \%$ de substituição da proteína de soja pela proteína do farelo de mamona, tanto aos 35 dias de idade quanto aos 56, diferindo significativamente apenas dos tratamentos $E$ e F.

Isto se deve ao maior peso médio das aves ocor rido nesse tratamento, apesar desse peso estatisticamente só ter sido superior à testemunha, aos 56 dias, não diferindo significativamente dos demais tratamentos aos 35 dias de idade das aves. 
7. CONCLUSOES

- farelo de mamona destoxicado, produzido comercialmente com 0 nome de "Lex Proteico", foi utilizddo em ensaio com frangos de corte.

Os resultados obtidos nas diversas fases de criação mostraram diferenças significativas entre os tratamentos, que permitia apresentar as seguintes conclasōes:

a) - To período de 0 a 35 dias de idade das aves, a ração contendo $11,60 \%$ de farelo de mamona promover o maior pe so médio corporal, embora tenha diferido significativamente apenas do tratamento $F(19,33 \%$ de farelo de mamona).

b) - A inclusão dos aíveis de 15,46 e 19,33\% do farelo de ma mona às rações, prejudicou o desenvolvimento de frangos de corte, de 0 a 35 dias de idade.

c) - O efeito depressivo observado no crescimento das aves que reeeberam ragōes com 15,46 e $19,33 \%$ de farelo de ma mona, parece ter sido causado pelo poder laxativo do óleo residual, presente no farelo de mamona, que ocasionou a eliminação de nutrientes parcialmente digeridos. 
d) - O consumo alimentar observado na fase inicial aumentou, apresentando variação significativa, em relação à teste munka, quando os níveis de substituição foram maiores que $10 \%$.

e) - A conversão alimentar observada na fase inicial apresen tou variação signficativa, em relação à testemunha, ape nas nos níveis de substituição de 40 e $50 \%$. Mostrou a tendência de piorar à medida que o nível de substitui̧̧ão se elevou.

f) - Na etapa final de criação ( 36 a 56 dias) e no total do periodo experimental ( 0 a 56 dias) as rações onde o nivel de substituição foi de $10 \%$, promoveram rebultados de ganho de peso superiores aos demais tratamentos, diferindo significativamente do tratamento $C$ na fase final e do tratamento A no total do experimento.

8) - Os demais níveis de substituição da proteina do farelo de soja pela do farelo de mamona, resultaram em dados bastante irregulares, tanto na fase final como no total do período experimental, o que impossibilitou a apresen tação de outras conclusões, referentes a ganho de peso médio.

h) - o consumo alimentar observado, nos períodos final e total, apresentou tendência de se elevar à medida que os níveis de substituição aumentaram.

i) - A conversão alimentar observada, nas fases final e total do experimento, apresentou resposta linear positiva aos níveis crescentes de adição do farelo de mamona às raçōes, apesar de não diferirem significativamente entre si fase final. Os tratamentos B, D, E e F foram significativamente maiores que a testemunha no total do período experimental. Por esses resultados, verifica- 
se que à medida que o nível do farelo aumentou nas rações, a conversão alimentar piorou.

j) - O efeito laxativo do óleo de mamona, apesar de não ter sido determinado por algum processo foi observado, e aumentou à medida que o nível do farelo de mamona foi elevado nas rações. Parece ser um fator limitante para utilização desse farelo na alimentação de frangos de corte. 
8. SUIMLARY

An experiment was carried out to evaluate the effects of substitution of soybean oil meal by detoxified castor oil meal on broiler performance. Eight hundred and sixty-four "Peterson" day old chicks were raised on floor from day-old to 56 days of age. The chicks were divided in 24 lots and each lot contained 18 birds of each sex. The chicks were fed six experimental aiets in which the proteins of castor oil meal substituted $0,10,20,30,40$ and $50 \%$ of the proteins of soybean 011 meal. Feed and water were supplied "ad libitum" - The birds were group weighed at weekly intervals. Feed consumption was recorded weeklJ.

The results showed that body weight and feed conversion were statisticaliy affected by the experimental. diets.

Regression analysis of body weight up to 35
days of age showed significant quadractic response $(P<0,01)$ to the addition of castor oil meal up to the level of $30 \%$ substitution. Feed consumption showed positive linear response $(P<0,01)$ and feed conversion, positive quadractic response $(\mathrm{P}<0,05)$ to increased levels of castor oil meal to 
the experimental diets. Although it was assumed that the experimental rations were calculated to be iso-caloric it was suggested that as castor oil meal increased in the rations energy would have decreased. It was concluded that the level of $10 \%$ of substitution gave the best economical returens in the experimental conditions. 
9. IITERATURA CITADA

AIILATRE, E., 1914. Etudes sur la ricine. III. Hypersensibi lité a la ricine. Ann. Inst. Pasteur, Paris, 28:605-607.

AIMEIDA, J.R., 1950. Elaiotecnia (Parte Teórica). Piracica ba, SP. Tipografia do Jornal de Piracicaba. 453 p.

AMBDEKAR, V.R. e K.K. DOLE, 1957. Detoxication of castor cake. Indian J. Dairy Sci., Bangalore, 10:107-122.

ANDERSON, T.S., 1948. Castor poisoning in the Ayrshire cattle, Vet. Rec., London, 60:28.

A.0.A.C. (ASSOCIATION OF OFFICIAI ANALYTICAL CHEMISTS), 1975. official Methods of Analysis. $12^{\text {th }}$ ed., Washington D.C. $1.015 \mathrm{p}$.

A.0.C.S. (ANEERICAN OII CHEMIST'S SOCIETY), 1967. OffICIAI and Tentative Methods of the American Oil Chemist's Society. $3^{\text {rd }}$ ed., Cincinaty, Ohio.

ASSIS, F.P., F. NAUPEL, A.G.A. TUNDISI, G.I. ROCHA, T.S. BRANCO, M. BECKERR e B. CINTRA, 1962. Valor do farelo de memona atoxicada na alimentação de vacas leiteiras, em comparação com os farelos de torta de algodão e de amendoim. Bol. Ind. Animal, são Paulo, 20:35-38.

AVIOULAURA BRASTHEIRA, 1977. São Paulo, v. 14, no 163.

AWOUWZRS, F., C.J.E. NIEMEGEERS, J. KUYPS P P.A.J. JANSSEN, 1975. Ioperamide antagonism of castor oil-induced diarrhea in rats. Arch. Int. Pharmacodyn. Ther., 217:2937. Citado no Chom. Abstr., Easton, 84, 1976. (ref. 12.470a). 
BALBACHAS, A., 1959. As plantas curan. São Paulo, SP. Edi tora Missionária "A Verdade Presente", 432 p.

BORCHERS, R., 1949. Castor bean oil meal. I. Destruction of the toxic factor. Poult. Sci., Ithaca, 28:568-570.

BRAGA, Z.A., H.I. MENDONÇA, J.A. GADETHA E A.G. CATUNDA, 1973. Efeito do farelo de mamona desintoxicado na produtividade de coelhos. Resumos dos trabalhos apresentados. na X Reunião Brasileira de Zootecnia, Porto Alegre, RS. $224-225$.

BUTZ, H. e Th. BOMTGER, 1937. Detoxified ground ricin residues in the concentrate mixture for milk cows. Ztachtungskunde, 12:98-100. Citado no Chem. Abstr., Easton, 32, 1938 (ref. 2.241-4).

CARVALHO, J.P., O.V. REIS, E.S. MONTEIRO, I.C. MENEZES e J. A. MORENO, 1976. Efeitos de diferentes niveis de farelo de mamona destoxicada na alimentação de poedeiras em gaio 1as. Anais da XIII Reunião da Sociedade Brasileira de Zootecnia. Salvador, BA. 222-223.

COSTA, B.I. e G.E. IAUN, 1961. Emprego da torta de mamona destoxicada na alimentação de pintos. Publicação no 38 do Instituto de Zootecnia do Ministério da Agricultura, Rio de Janeiro, 19 p.

FAO, 1975a. Situacion I perspectivas de los productos basicos de 1974-1925. Organizacion de las Naciones Unidas pa ra la Agricultura y la Alimentacion, Roma. 268 p.

FAO, 19750. Anuário de Producão, 29, p. 106.

FIGLEI, R.D. e R.H. EIROD, 1928. Endemic asthma due to castor bean dust. J. Ho. Med. Assoc., 90:79-82. Citado no Chem. Abstr., Easton, 22:2.283, 1928. 
FULLER, G., H.G. WAIKER, Jr., A.C. MOTTOLA, D.D. KUZMICKY e G.0. KOHLER, 1971. Potential for detoxified castor meal. J. Amer. Oil Chem. Soc., Champaign, 48:616-618.

FUNATSU, M., K. MURASE, M. MATSUOKA, T. TAKAHASHI, M. ISHIGU RO, S. OKAMOTO e I. GOTO, 1963. Investigation of evaluation of castor seed residues as cattle fodder. I. Detoxi cation of castor seed residues. Sci. Bull. Fac. Agr., Fukuoka, 20:247-258.

GADETHA, J.A., A.V. SILVA \& M.F.M. FREIRE, 1969. Substituição parcial de concentrado comercial por torta de mamona atoxicada, em rações de frango de corte. Bol. Cear. Agron., Fortaleza, CE, 10:17-22.

GADETHA, J.A., M.F.F. FUENTES, H.I. MENDONÇA \& R.M.A. PEREIRA, 1973. Substituição do farelo de soja pelo de mamona desintoxicado em raçōes de pintos. Cien. Agron., Fortale za, CE, 3:71-74.

GOMES, F.P., 1976. Curso de Estatistica Experimental. 6a d., Piracicaba, SP. Editora Livraria Nobel S/A. 430 p.

I.B.G.E. (INSTITUTO BRASILEIRO DE GEOGRAFIA E ESTATISTICA), 1976. Anuário Estatístico do Brasil, Fund. I.B.G.E., Rio de Janeiro, 32, p. 170.

INSTITUTO DE ECONOMIA AGRICOIA DO ESTADO DE SAO PAULO, 1977. Informações Económicas, Sáo Paulo, SP. v. 7, n? 3, p. 6.

JENKINS, F.P., 1963. Allergenic and toxic components of castor bean meal: Review of the literature and studies of the inactivation of these components. J. Sci. Food Agric. Iondon, 14:773-780.

JONES, D.B., 1947. Protein of the castor bean, their preparation, properties and utilization, J. As, Oil Chem. Soc. Champaign, 24:247-251. 
KABAT, E.A., P. HEIDTEBERGER \& A.E. BEZER, 1947. A study of purification and properties of ricin. J. Biol. Chem., Baltimore, 168: 629-639.

KHAN, N.A., A. SATTMA, M.F. KUQ E M.A. HOSATN, 1968. Oil cakes: features of inedible cakes and their utilization. Sci. Res., Dacca, 5:114-117. Citado no Chem. Abstr., Easton, 20:79, 1969. (ref. 59.127 v).

KODRAS, R., C.R. WHITEHAIR E R. MACVICAR, 1949. Studies on the detoxication of castor seed pomace. J. Am. Oil Chem. Soc., Champaign, 26:641-644.

KUMANOV, S. e P. VOICHEV, 1954. Influence of sunflower, linseed, castor seed and grapeseed meals on the egg production of hens. Nauch. Trudove, Sofia, 475:41-50. Cita do no Nutr. Abstr. and Rew., Aberdeen, 26:542, 1956 (ref. 2.586).

IAUN, G.P. e B.I. COSTA, 1962. Emprego da torta de mamona detoxicada na alimentaçäo de poedeiras, Publicação no 46 do Instituto de Zootecnia do Ministério da Agricultura, Rio de Janeiro. 12 p.

LECOQ, R., 1942. Unbalanced diets and vitamins. Chimie \& Ind., 47:255. Citado no Chem. Abstr., Easton, 40, 1946 ( $r \in f .7 .329)$.

IOUREIRO, M.C., 2962. Torta de semente de mamoneira na alimentação animal. Revista Ceres, Viçosa, MG, 11:290-294.

MIRANDA, R.M., H.A. BARREIRA, E.V. FARIA E D.D. MACHADO, 1961. O farelo de mamona detoxicado na alimentação de no vilhas leiteiras. Publicação $n$ ㅇ 41 do Inst. Zootec. do Ministério da Agricultura, Rio de Janeiro. 12 p. 
POLIAKOFF, J., 1960. Note sur la production du torteau de ricin désintoxiqué par une societé bresilienne. Son emploi dans l'alimentation du bétail. Oleagineux, Paris, 15:793-795.

POIIT, P.F. e V.C. SGARBIERI, 1976. Some physicochemical and nutritional properties of castor bean. J. Agric. Food. Chem., Easton, 24:795-798.

PRAKHIN, M.E., S.M. KABOZOV \& A.A. ZHURAVET, 1952. Castor cake and castor grist (rendered innocuos by industrial processes), a new protein fodder for farm animals. Sovet 2ootelch., 2:64-74. Citado no Nutr. Abstr. and Rew., Aberdeen, 23:661, 1953 (ref. 3.616).

RAIMO, H.F., 1958. Soja e farelo de mamona na alimentação das aves. Revista Rio-Avicola, outubro, 1958.

RAYMOND, W.D., 1961. Castor beans as food and fodder. Trop. Sci., London, 38:19-24.

REYNET, P.C. e G.H. SPRAY, 1958. Chenical gastroenterites in the rat. Gastroenterology, 34:867-873. Citado no Chem. Abstr., Easton, 52, 1958. (ref. 14.8621).

ROBB, J.G., R.C. IABEN, H.G. WAJKER E V. HERRTWG, 1974. Castor meal in dairy rations. J. Dairy Sci., Urbana, 57: $443-450$.

ROSERBERG, M.M., 1953. A study of B-grade and refinary B-molasses in layer rations. Poult. Sci., Ithaca, 22 : $605-612$.

ROYER, M. e P.A. MAZURE, 1951. Rate of tronsit in the normal human intestíne. Rev. Soc. Arg. Biol., Buenos Aires, 27:210-219. Citado no Chem. Abstr., Easton, 46, 1952 (ref. 10.421i). 
MURASE, K., S. KUSAKAWA, C. YAMAGUCHI, T. TAKAHASHI, M. FUHATSU, I. GOMO, O. KOGA e S. OKAMOTO, 1966. On the toxicity of ricinine contained in castor meal. J. Agr. Chem. Soc. Japan, Tokyo, 40:61-66.

NUNES, J.R.V., 1972. Emprego do farelo de mamona como fonte proteica para suínos. Anais da II Jornada Cientifica da Faculdade de Ciências Médicas e Biológicas de Botucatu. Botucatu, SP. p. 20.

OKAMOTO, S., O. HOGA, I. GOTO, M. FUNATSU, M. MATSUOZA e I. MURASE, 1963. Studies on utilization of castor pomace for an animal feed. II. Availability tests of the autoclaved pomace as an ingredient of broiler and layer rations. Sci. Bull. Fac. Agric., Fukuoka, 20:259-264.

OKAMOTO, S., O. KOGA, I. GOTO, T. ARAMAKI, M. FUNATSU, T. TAKAHASHI, C. YAMAGUCHI, S. KUSAKAVA e K. MURASE, 1965. Studies on utilzation of castor pomace for an animal feed. III. Further studies on detoxification and araila bility as a poultry feed. Japan. Poult. Sci., 2:1-10.

OSER, B.L., ed., 1965. Hawk's Physiological Chemistry. New York, McGraw Hill. $1.472 \mathrm{p}$.

PERRONE, J.C., A. IACHAN, G.B. DOMONT, L.V. DISITZER, V.R. OSORIO e CASTRO, R. ROITMAN E S.M. GOMER, 1966. Contribuição ao estudo da torta de mamona. Rio de Janeiro, Instituto Nacional de Tecnologia do Ministério da Indústria e do comércio. $51 \mathrm{p}$.

PEIROSIAN, E. e V. PONOMAREV, 1934. Use of castor cake for pig feeding. Schweinezucht, 4:33. Citado no Chem. Abstr., Easton, 31, 1937 (ref. 7.554-2). 
ROYER, M. e P.A. MAZURE, 2952. Pharmacology of the small intestine. Medicina, Buenos Aires, 12:298-318. Citado no Chem. Abstr., Easton, 47, 1953. (ref. 2.363e).

RYBIHA, E.T., 1958. Influence of feed protein on growth of chickens and egs production of hens. Pticevodstvo, 3: 35-37. Citado no Nutr. Abstr. and Rew., Aberdeen, 28: 950, 1958 (ref. 4.492).

SCOMT, M.I., M.C. IESHEIM A R.J. YOUNG, 1969. Nutrition of the Chicken. Ithaca, New York. M.I. Scott \& Associates. $511 \mathrm{p}$.

SEVKOVIC, M., M. POPOVIC e Ij. BASARIC, 1966. Possibility of using castor oilmeal for feeding livestock. Vet. Glasnik, 20:259-263. Citado no Mutr. Abstr. and Rew., Aberdeen, 32:239, 1967. (ref. 1.466).

SPIES, J.R., H.S. BERUTON e H. STEVENS, 1941. The chemistry of aljergens. IV. An electrophoretic fractionation of the protein-polysaccharide fraction, CS-1A, from cottonseed. J. Am. Chem. Soc., Easton, 63:2163-2169.

SPIES, J.R. \& E.J. COULSON, 1943. The chemistry of allergens. VIII. Isolation and properties of an active protein-polysaccharide fraction, CB-1A, from castor beans. J. Am. Chem. Soc., Easton, 65:1720-1725.

TANGI, H., 1938. The feeding value of the extracted castor oil meal. Kisérletugyi Koslemények, 41:69-72. Citado no Chem. Abstr., Easton, 33, 1939. (ref. 7.422-1).

VIIHJAIMSDOTRIR, L. e H. FISHER, 1971. Castor bean meal as a protein source for chickens: detoxification and determi nation of limiting amino acids. J. Nutrition, Philadelphia, 101:1185-1192. 
WAJTER, F.R. e S.S. NEGI, 1958. Isolation of ricin, ricinine and the allergenic fraction from castor seed pomace from two different sources. J. Am. Oil Chem. Soc., Champaign, 33:409-412. 
89.

10. APENDICE 
Tabela 27. Peso mẻdio, consumo de ração médio e conversão ali mentar média nas parcelas, aos 35 dias de idade das aves

\section{PESO MEDIO ( $\mathrm{kg}$ )}

\begin{tabular}{|c|c|c|c|c|c|c|c|}
\hline \multirow{2}{*}{$\begin{array}{l}\text { BIo } \\
\text { cos }\end{array}$} & \multicolumn{6}{|c|}{ Tratamentos } & \multirow{2}{*}{$\begin{array}{l}\text { Total } \\
\text { Blocos }\end{array}$} \\
\hline & A & B & C & $D$ & $E$ & $\mathbf{F}$ & \\
\hline I & 0,994 & 1,036 & 1,002 & 1,019 & 1,008 & 0,981 & 6,040 \\
\hline II & 0,984 & 0,994 & 0,999 & 1,043 & 0,991 & 0,956 & 5,967 \\
\hline III & 0,936 & 1,017 & 1,015 & 0,995 & 1,013 & 0,965 & 5,941 \\
\hline IV & 0,997 & 0,984 & 1,015 & 1,027 & 1,012 & 0,995 & 6,030 \\
\hline Média & 0,978 & 1,008 & 1,008 & 1,021 & 1,006 & 0,974 & 0,999 \\
\hline
\end{tabular}

CONSUMO DE RAÇAO ( $\mathrm{kg}$ )

\begin{tabular}{llllllll}
\hline I & 1,811 & 1,933 & 1,921 & 1,969 & 2,007 & 2,020 & 11,661 \\
II & 1,866 & 1,877 & 1,941 & 2,008 & 1,969 & 1,961 & 11,622 \\
III & 1,825 & 1,952 & 1,982 & 1,920 & 2,000 & 1,942 & 11,621 \\
IV & 1,913 & 1,944 & 1,999 & 1,979 & 1,982 & 2,086 & 11,903 \\
Média & 1,854 & 1,926 & 1,961 & 1,969 & 1,989 & 2,002 & 1,950
\end{tabular}

CONVERSAO AIIMENTAR

\begin{tabular}{lrlllllll}
\hline I & 1,822 & 1,866 & 1,917 & 1,932 & 1,991 & 2,059 & 11,587 \\
II & 1,896 & 1,888 & 1,943 & 1,925 & 1,987 & 2,051 & 11,690 \\
III & 1,950 & 1,919 & 1,953 & 1,930 & 1,974 & 2,012 & 11,738 \\
IV & 1,919 & 1,976 & 1,969 & 1,927 & 1,959 & 2,096 & 11,846 \\
Média & 1,897 & 1,912 & 1,945 & 1,928 & 1,978 & 2,054 & 1,952 \\
\hline
\end{tabular}


91.

Tabela 28. Ganho de peso médio, consumo de ração média e conversão alimentar média nas parcelas, entre 36 e 56 dias de idade das aves

\section{GANHO DE PESO ( $\mathrm{kg}$ )}

\begin{tabular}{|c|c|c|c|c|c|c|c|}
\hline \multirow{2}{*}{$\begin{array}{l}\mathrm{BlO} O \\
\mathrm{cos}\end{array}$} & \multicolumn{6}{|c|}{ Tratamentos } & \multirow{2}{*}{$\begin{array}{l}\text { Total } \\
\text { Blocos }\end{array}$} \\
\hline & A & B & C & $D$ & $E$ & $F$ & \\
\hline I & 0,955 & 1,006 & 0,932 & 0,980 & 0,981 & 1,029 & 5,883 \\
\hline II & 0,980 & 1,026 & 0,989 & 0,998 & 0,968 & 0,999 & 5,960 \\
\hline III & 0,933 & 1,006 & 0,983 & 1,005 & 0,947 & 1,020 & 5,894 \\
\hline IV & 1,019 & 1,047 & 0,940 & 0,995 & 1,014 & 1,018 & 6,033 \\
\hline Média & 0,972 & 1,021 & 0,961 & 0,994 & 0,977 & 1,016 & 0,990 \\
\hline
\end{tabular}

CONSUMO DE RAÇÃO (kg)

\begin{tabular}{lrlllllll}
\hline I & 2,660 & 2,823 & 2,668 & 2,741 & 2,872 & 2,908 & 16,672 \\
II & 2,704 & 3,007 & 2,806 & 2,986 & 2,825 & 2,954 & 17,282 \\
III & 2,685 & 2,836 & 2,761 & 2,816 & 2,839 & 3,001 & 16,938 \\
IV & 2,754 & 2,815 & 2,867 & 2,783 & 2,842 & 2,932 & 16,993 \\
Média & 2,701 & 2,870 & 2,775 & 2,831 & 2,844 & 2,949 & 2,828 \\
\hline
\end{tabular}

CONVERSAO ALIMENTAR

\begin{tabular}{lrllllll}
\hline I & 2,785 & 2,806 & 2,863 & 2,797 & 2,928 & 2,826 & 17,005 \\
II & 2,759 & 2,931 & 2,837 & 2,992 & 2,918 & 2,957 & 17,394 \\
III & 2,878 & 2,819 & 2,809 & 2,802 & 2,998 & 2,942 & 17,248 \\
IV & 2,703 & 2,689 & 3,050 & 2,797 & 2,803 & 2,880 & 16,922 \\
Média & 2,781 & 2,811 & 2,890 & 2,847 & 2,912 & 2,901 & 2,857
\end{tabular}


Tabela 29. Peso médio, consumo de ração médio e conversão ali mentar média nas parcelas, aos 56 dias de idade das aves

PESO MEDIO ( $\mathrm{kg})$

\begin{tabular}{|c|c|c|c|c|c|c|c|}
\hline \multirow{2}{*}{$\begin{array}{l}\mathrm{BIO} \\
\cos \end{array}$} & \multicolumn{6}{|c|}{ Tratamentos } & \multirow{2}{*}{$\begin{array}{r}\text { Total } \\
\text { Blocos }\end{array}$} \\
\hline & A & B & C & $D$ & $E$ & $P$ & \\
\hline$I$ & 1,949 & 2,042 & 1,934 & 1,999 & 1,989 & 2,010 & 11,923 \\
\hline II & 1,964 & 2,020 & 1,988 & 2,041 & 1,959 & 1,955 & 11,927 \\
\hline III & 1,869 & 2,023 & 1,998 & 2,000 & 1,960 & 1,985 & 11,835 \\
\hline IV & 2,016 & 2,031 & 1,955 & 2,022 & 2,026 & 2,013 & 12,063 \\
\hline Média & 1,949 & 2,029 & 1,969 & 2,015 & 1,983 & 1,991 & 1,989 \\
\hline
\end{tabular}

\section{CONSUMO DE RAÇAO ( $\mathrm{kg}$ )}

\begin{tabular}{lrlllllll}
\hline I & 4,471 & 4,756 & 4,589 & 4,710 & 4,879 & 4,928 & 28,333 \\
II & 4,570 & 4,884 & 4,747 & 4,994 & 4,794 & 4,915 & 28,904 \\
III & 4,510 & 4,788 & 4,743 & 4,736 & 4,839 & 4,943 & 28,559 \\
IV & 4,667 & 4,759 & 4,866 & 4,762 & 4,824 & 5,018 & 28,896 \\
Média & 4,554 & 4,797 & 4,736 & 4,800 & 4,834 & 4,951 & 4,779
\end{tabular}

CONVERSATO ALIMEUNTAR

\begin{tabular}{lllllllll}
\hline I & 2,294 & 2,329 & 2,373 & 2,356 & 2,453 & 2,452 & 14,257 \\
II & 2,737 & 2,418 & 2,388 & 2,447 & 2,447 & 2,514 & 14,541 \\
III & 2,413 & 2,367 & 2,374 & 2,368 & 2,469 & 2,490 & 14,481 \\
IV & 2,315 & 2,343 & 2,489 & 2,355 & 2,381 & 2,493 & 14,376 \\
Média & 2,337 & 2,364 & 2,406 & 2,381 & 2,437 & 2,487 & 2,402
\end{tabular}


Tabela 30. Valores médios da umidade relativa do ar e das temperaturas minima, média e mảxima, durante o experimento.

Umidade relatira média do ar (\%)

\begin{tabular}{lllllllll}
\hline 11 a 35 dias & 98,80 & 61,12 & 65,91 & 91,56 & 93,04 & 95,28 \\
36 a 56 dias & 91,76 & 54,66 & 57,35 & 88,95 & 90,75 & 93,50 \\
11 a 56 dias & 93,41 & 58,17 & 62,02 & 90,40 & 92,02 & 94,48
\end{tabular}

Temperatura media (으)

11 a 35 dias

15,33

21,02

26,70

36 a 56 dias

11,00

17,10

23,19

11 a 56 dias

13,31

19,18

25,06 